\title{
Attribution of spatial and temporal variations in terrestrial methane flux over North America
}

\author{
X. F. Xu' ${ }^{1,2}$, H. Q. Tian ${ }^{1,2}$, C. Zhang ${ }^{1}$, M. L. Liu ${ }^{1,2}$, W. Ren $^{1,2}$, G. S. Chen ${ }^{1,2}$, C. Q. Lu ${ }^{1,2}$, and L. Bruhwiler ${ }^{3}$ \\ ${ }^{1}$ Ecosystem Dynamics and Global Ecology (EDGE) Laboratory, School of Forestry and Wildlife Sciences, \\ Auburn University, Auburn, AL, 36849, USA \\ ${ }^{2}$ International Center for Climate and Global Change Research, Auburn University, Auburn, AL, 36849, USA \\ ${ }^{3}$ NOAA Earth System Research Laboratory, 325 Broadway, Boulder, CO 80305-3337, USA
}

Received: 27 April 2010 - Published in Biogeosciences Discuss.: 13 July 2010

Revised: 29 October 2010 - Accepted: 29 October 2010 - Published: 12 November 2010

\begin{abstract}
The attribution of spatial and temporal variations in terrestrial methane $\left(\mathrm{CH}_{4}\right)$ flux is essential for assessing and mitigating $\mathrm{CH}_{4}$ emission from terrestrial ecosystems. In this study, we used a process-based model, the Dynamic Land Ecosystem Model (DLEM), in conjunction with spatial data of six major environmental factors to attribute the spatial and temporal variations in the terrestrial methane $\left(\mathrm{CH}_{4}\right)$ flux over North America from 1979 to 2008 to six individual driving factors and their interaction. Over the past three decades, our simulations indicate that global change factors accumulatively contributed $23.51 \pm 9.61 \mathrm{Tg} \mathrm{CH}_{4}-\mathrm{C}\left(1 \mathrm{Tg}=10^{12} \mathrm{~g}\right)$ emission over North America, among which ozone $\left(\mathrm{O}_{3}\right)$ pollution led to a reduced $\mathrm{CH}_{4}$ emission by $2.30 \pm 0.49 \mathrm{Tg} \mathrm{CH}_{4}-\mathrm{C}$. All other factors including climate variability, nitrogen $(\mathrm{N})$ deposition, elevated atmospheric carbon dioxide $\left(\mathrm{CO}_{2}\right), \mathrm{N}$ fertilizer application, and land conversion enhanced terrestrial $\mathrm{CH}_{4}$ emissions by $19.80 \pm 12.42 \mathrm{~T} \mathrm{~g} \mathrm{CH}_{4}-\mathrm{C}, 0.09 \pm 0.02$ $\mathrm{Tg} \mathrm{CH} 4-\mathrm{C}, 6.80 \pm 0.86 \mathrm{~T} \mathrm{~g} \mathrm{CH}_{4}-\mathrm{C}, 0.01 \pm 0.001 \mathrm{~T} \mathrm{~g} \mathrm{CH}_{4}-\mathrm{C}$, and $3.95 \pm 0.38 \mathrm{~T} \mathrm{~g} \mathrm{CH}_{4}-\mathrm{C}$, respectively, and interaction between/among these global change factors led to a decline of $\mathrm{CH}_{4}$ emission by $4.84 \pm 7.74 \mathrm{~T} \mathrm{~g} \mathrm{CH}_{4}$-C. Climate variability and $\mathrm{O}_{3}$ pollution suppressed, while other factors stimulated $\mathrm{CH}_{4}$ emission over the USA; climate variability significantly enhanced, while all the other factors exerted minor effects, positive or negative, on $\mathrm{CH}_{4}$ emission in Canada; Mexico functioned as a sink for atmospheric $\mathrm{CH}_{4}$ with a major contribution from climate change. Climatic variability dominated the inter-annual variations in terrestrial $\mathrm{CH}_{4}$ flux at both continental and country levels. Precipitation played
\end{abstract}

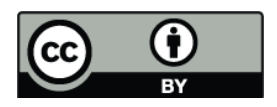

Correspondence to: H. Q. Tian (tianhan@auburn.edu) an important role in the climate-induced changes in terrestrial $\mathrm{CH}_{4}$ flux at both continental and country-levels. The relative importance of each environmental factor in determining the magnitude of $\mathrm{CH}_{4}$ flux showed substantially spatial variation across North America. This factorial attribution of $\mathrm{CH}_{4}$ flux in North America might benefit policy makers who would like to curb climate warming by reducing $\mathrm{CH}_{4}$ emission.

\section{Introduction}

Following carbon dioxide $\left(\mathrm{CO}_{2}\right)$, methane $\left(\mathrm{CH}_{4}\right)$ is the second most radiatively important anthropogenic greenhouse gas which contributes approximately 15\% (Rodhe, 1990), or even higher (Shindell et al., 2005), to the increases in radiative forcing caused by anthropogenic release of greenhouse gases to the atmosphere (Lelieveld and Crutzen, 1992; Forster et al., 2007). Current regional estimates of $\mathrm{CH}_{4}$ flux, however, are far from certain not only because of the complexity of biotic and abiotic processes responsible for the production and consumption of $\mathrm{CH}_{4}$ (Bousquet et al., 2006; Conrad, 1996), but also because of the limitations and uncertainties in the approaches used for estimations (Denman et al., 2007; Tian et al., 2010a); for example, the uncertainties in the methods of up-scaling and down-scaling (Chen and Prinn, 2006; Liu, 1996), biases in observational data (Sellers et al., 1997; Song et al., 2009; Moosavi et al., 1996), and the uncertainties caused by weakened high spatial heterogeneity of ecosystem properties in the regional estimation of $\mathrm{CH}_{4}$ flux (Frolking and Crill, 1994; Mastepanov et al., 2008; Ding et al., 2004a). Process-based modeling approach has become more and more important in regional estimation of $\mathrm{CH}_{4}$ flux because it bases on the understanding of biogeochemistry of

Published by Copernicus Publications on behalf of the European Geosciences Union. 
$\mathrm{CH}_{4}$ production and consumption, and incorporates the effects of spatial and temporal heterogeneities of major environmental controls on $\mathrm{CH}_{4}$ processes (Tian et al., 2010a; Potter et al., 2006; Potter, 1997; Walter et al., 2001; Zhuang et al., 2004).

One of the most challenging issues for process-based modeling approach, however, is the gap between reality and "virtual reality" in models for simulating all major processes and environmental factors responsible for $\mathrm{CH}_{4}$ production and consumption (Schimel, 2001; Tian et al., 2008; Conrad, 1996). The controlling factors for $\mathrm{CH}_{4}$ production and consumption have been identified as substrates including dissolved organic carbon, $\mathrm{CO}_{2}$, and methanol, and environmental factors including soil $\mathrm{pH}$, oxygen concentration, moisture, temperature, and nitrate concentration etc. (Mer and Roger, 2001; Conrad, 1996). In the globally changing environment, a number of factors may change these substrates and/or environmental factors and further alter $\mathrm{CH}_{4}$ production and consumption; for instance, elevated atmospheric $\mathrm{CO}_{2}$ may enhance $\mathrm{CH}_{4}$ emission by stimulating $\mathrm{CH}_{4}$ production (Hutchin et al., 1995) or reduce $\mathrm{CH}_{4}$ oxidation in soils (Phillips et al., 2001); $\mathrm{O}_{3}$ pollution might suppress $\mathrm{CH}_{4}$ emission (Morsky et al., 2008); climate change may increase or decrease $\mathrm{CH}_{4}$ emission (Cao et al., 1998; Frolking and Crill, 1994; Martikainen et al., 1993); N input (Ding et al., 2004b) including $\mathrm{N}$ deposition (Steudler et al., 1989) and N fertilization (Zou et al., 2005) might increase (Börjesson and Nohrstedt, 1998; Bodelier et al., 2000) or decrease (Mer and Roger, 2001; Liu and Greaver, 2009; Steudler et al., 1989) $\mathrm{CH}_{4}$ oxidation; and changes in land cover types may increase or decrease $\mathrm{CH}_{4}$ flux, depending on the direction of land conversion (Willison et al., 1995; Huang et al., 2010; Jiang et al., 2009).

In the changing world to which multiple global change factors contribute individually or in combination (Heimann and Reichstein, 2008), attributing the variations in regional terrestrial $\mathrm{CH}_{4}$ flux to these global change factors is of great significance for understanding atmospheric $\mathrm{CH}_{4}$ dynamics and for policy-making to curb the increase in atmospheric $\mathrm{CH}_{4}$ concentration. Yet, most previous process-based modeling efforts did not simultaneously take into account the effects of these global change factors in the estimations of regional $\mathrm{CH}_{4}$ flux (Cao et al., 1998; Potter, 1997; Zhuang et al., 2007). For instance, Zhuang et al.'s studies only considered the effects of climate variability, rising atmospheric $\mathrm{CO}_{2}$, and land classification; other factors including changes of land cover, $\mathrm{N}$ deposition, and $\mathrm{O}_{3}$ pollution, were not considered (Zhuang et al., 2004, 2007); most other studies even simulated solely the effects of climate variability (Cao et al., 1998; Potter, 1997; Walter et al., 2001). Given the complicated effects of multiple global change factors on $\mathrm{CH}_{4}$ production and oxidation (Amaral et al., 1998; Börjesson and Nohrstedt, 1998; Mer and Roger, 2001), and high spatial and temporal heterogeneities of global change factors (Denman et al., 2007; Heimann and Reichstein, 2008), it is urgent to si- multaneously incorporate multiple global change factors into the simulation of $\mathrm{CH}_{4}$ flux for evaluating the relative contributions from each factor to the spatial and temporal variations in terrestrial $\mathrm{CH}_{4}$ flux at large scale (Bousquet et al., 2006).

North America, one of the extensively studied continents on $\mathrm{CH}_{4}$ budget, is still short of quantification on the relative contributions from global change factors to terrestrial $\mathrm{CH}_{4}$ flux (Bridgham et al., 2006; Potter et al., 2006). In our previous study (Tian et al., 2010a), the continental and country-level fluxes of $\mathrm{CH}_{4}$ over North America's terrestrial ecosystems during 1979-2008 have been estimated by using a process-based ecosystem model, Dynamic Land Ecosystem Model (DLEM), driven by multiple global change factors including climate variability, rising atmospheric $\mathrm{CO}_{2}, \mathrm{O}_{3}$ pollution, $\mathrm{N}$ deposition, land use change, and $\mathrm{N}$ fertilizer application. In this study, we will advance our analysis with emphasis on the attribution of the spatial and temporal variations in terrestrial $\mathrm{CH}_{4}$ flux to multiple global change factors at both continental and country levels.

Specifically, the objectives of this study are (1) to examine the factorial contributions to the spatial variation of terrestrial $\mathrm{CH}_{4}$ flux over North America during 1979-2008; (2) to quantify the factorial contributions to the temporal variations in terrestrial $\mathrm{CH}_{4}$ flux over North America during 19792008; (3) to quantify the factorial contributions to the 30year accumulated fluxes of $\mathrm{CH}_{4}$ over North America at both continental and country levels; and (4) to identify the major factors responsible for the spatial and temporal variations in terrestrial $\mathrm{CH}_{4}$ fluxes at both continental and country levels. The global change factors that will be evaluated in this study include climate variability, elevated atmospheric $\mathrm{CO}_{2}, \mathrm{~N}$ deposition, $\mathrm{O}_{3}$ pollution, changes in land use and land cover types, and $\mathrm{N}$ fertilizer application. The interactive effects among these six factors were calculated by subtracting the changes in $\mathrm{CH}_{4}$ flux resulted from the combined effects of changes in $\mathrm{CH}_{4}$ flux caused by individual effect from each factor (see Experiment design section for the detail information).

\section{Materials and methods}

\subsection{Brief description of the model used in this study}

The model used in this study is called the Dynamic Land Ecosystem Model (DLEM) which couples major biogeochemical cycles, hydrological cycles, and vegetation dynamics to make daily, spatially-explicit estimates of carbon $(\mathrm{C})$, nitrogen $(\mathrm{N})$, and water fluxes and pool sizes in terrestrial ecosystems (Tian et al., 2008, 2010a, b; Ren et al., 2007; Liu et al., 2008; Zhang et al., 2007). The DLEM also simulates the managed ecosystems including agricultural ecosystems, plantation forests and pastures. The spatial data set of land management, such as irrigation, fertilizer 
application, rotation, and harvest can be used as input information for simulating influences of land management on the structure and functioning of ecosystems. This model has been calibrated against various field data from the Chinese Ecological Research Network (CERN), US Long-Term Ecological Research (LTER) network, and AmeriFlux network which cover various ecosystems, including forests, grasslands, shrub, tundra, desert, wetland, and croplands. The simulated results have been compared with independent field data and satellite products. The DLEM operates at a daily time step and at a variety of spatial scales ranging from meters to kilometers, from regional to global. The detailed information for DLEM could be referred to our previous publications (Chen et al., 2006; Liu et al., 2008; Ren et al., 2007; Zhang et al., 2007a; Ren, 2009; Zhang, 2008; Lu, 2009; Tian et al., 2010b; $\mathrm{Xu}, 2010$ ), and the $\mathrm{CH}_{4}$ module has been described in detail in Tian et al. (2010a).

The methane module in the DLEM model mainly simulates the production, consumption, and transport of $\mathrm{CH}_{4}$ (Fig. 1). Due to the relatively small contribution from other substrates (Conrad, 1996; Mer and Roger, 2001), DLEM only considers the $\mathrm{CH}_{4}$ production from dissolved organic carbon (DOC), which is indirectly controlled by environmental factors including soil $\mathrm{pH}$, temperature and soil moisture content. The DOC was produced through three pathways, GPP allocation, and side products from soil organic matter and litter-fall decomposition. $\mathrm{CH}_{4}$ oxidation, including the oxidation during $\mathrm{CH}_{4}$ transport to the atmosphere, $\mathrm{CH}_{4}$ oxidation in the soil/water, and atmospheric $\mathrm{CH}_{4}$ oxidation on the soil surface, is determined by $\mathrm{CH}_{4}$ concentrations in the air or soil/water, as well as soil moisture, $\mathrm{pH}$, and temperature. Most $\mathrm{CH}_{4}$-related biogeochemical reactions in the DLEM were described as the Michaelis-Menten equation with two coefficients: maximum reaction rate and half-saturated coefficient. Three pathways for $\mathrm{CH}_{4}$ transport from soil to the atmosphere including ebullition, diffusion, and plant-mediated transport, are considered in the DLEM (Tian et al., 2010a).

Multiple global change factors yield direct and/or indirect impacts on $\mathrm{CH}_{4}$ processes as simulated in the DLEM (Fig. 1), which could be expressed as the following equation.

$$
\begin{aligned}
F_{\mathrm{CH}_{4}} & =V_{\text {maxprod }} f\left(C_{\mathrm{a}}, \mathrm{w}, T_{\text {air }}, \mathrm{APAR}\right) f\left(\mathrm{O}_{3}\right) f(\mathrm{~N}) \\
& -V_{\text {maxoxid }} f\left(T_{\text {soil }}, \text { WFPS }\right)
\end{aligned}
$$

where $F_{\mathrm{CH}_{4}}$ is the $\mathrm{CH}_{4}$ flux; $V_{\text {maxprod }}$ is the maximum rate of $\mathrm{CH}_{4}$ production; $f\left(C_{\mathrm{a}}, \mathrm{w}, T_{\mathrm{air}}, \mathrm{APAR}\right)$ describes the indirect effects of atmospheric $\mathrm{CO}_{2}$ concentration, soil moisture, air temperature, and absorbed photosynthetically active radiation on $\mathrm{CH}_{4}$ production through their effects on photosynthesis; $f\left(\mathrm{O}_{3}\right)$ describes the indirect effects of $\mathrm{O}_{3}$ pollution on $\mathrm{CH}_{4}$ flux via its effects on photosynthesis; $f(\mathrm{~N})$ describes the indirect effects of $\mathrm{N}$ input on $\mathrm{CH}_{4}$ production through its impacts on photosynthesis and ecosystem respiration; $C_{\mathrm{a}}$ is atmospheric $\mathrm{CO}_{2}$ concentration, $\mathrm{w}$ is soil moisture; $T_{\text {air }}$ is

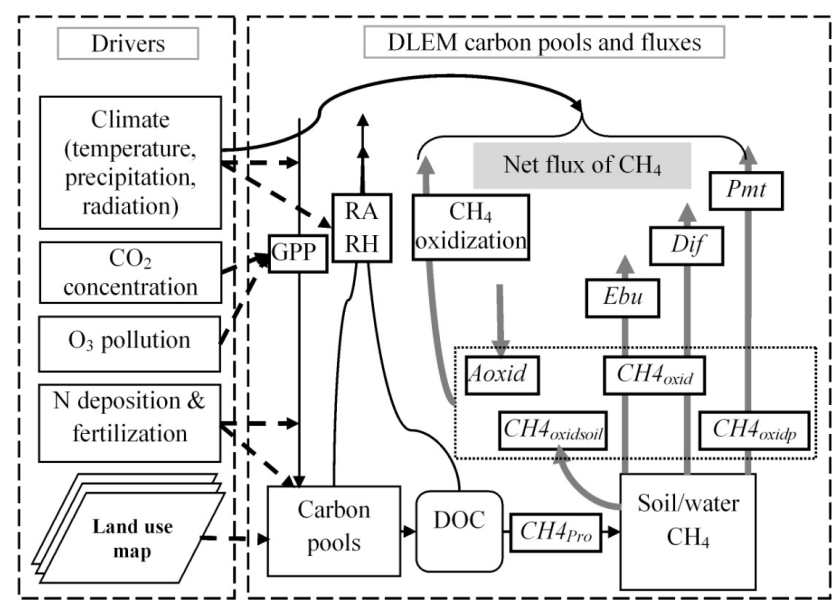

Major processes: Aoxid: Atmospheric $\mathrm{CH}_{4}$ oxidation; $\mathrm{CH}_{4}$ pro: $\mathrm{CH}_{4}$ production; $\mathrm{CH}_{4}$ oxid: $\mathrm{CH}_{4}$ Oxidation during diffusion and ebullition transport; $\mathrm{CH}_{4}$ oxidp: $\mathrm{CH}_{4}$ oxidation during plant-mediated transport; $\mathrm{CH}_{4}$ oxidsoil $: \mathrm{CH}_{4}$ oxidation in soil; Dif: $\mathrm{CH}_{4}$ diffusion transport; Ebu: $\mathrm{CH}_{4}$ ebullition transport; Pmt: Plant-mediated transport of $\mathrm{CH}_{4}$ (Occur in herbaceous wetland only); GPP is the gross primary production, RA is the autotrophic respiration from plant, and RH is the heterotrophic respiration; DOC is the dissolved organic carbon. Drivers are the multiple global change factors which yield controls on or feedback to ecosystem processes in the DLEM framework. The effects from drivers were expressed as the line starting from drivers to ecosystem processes or pools. Solid lines represent direct, while dash lines represent indirect impacts on $\mathrm{CH}_{4}$ processes.

Fig. 1. Conceptual diagram showing major processes for $\mathrm{CH}_{4}$ production, oxidation and transport from the soil/water to the atmosphere in response to multiple global change factors.

air temperature, APAR is absorbed photosynthetically active radiation. $V_{\text {maxoxid }}$ is the maximum rate of $\mathrm{CH}_{4}$ oxidation, which could be each of three oxidation processes simulated in the DLEM; $f\left(T_{\text {soil }}\right.$, WFPS $)$ describes the direct effects of soil temperature and moisture on $\mathrm{CH}_{4}$ oxidation; $T_{\text {soil }}$ is soil temperature, WFPS is water filled pore space. It should be noted that WFPS is directly related to precipitation. Meanwhile, soil temperature, $\mathrm{pH}$ and moisture directly influence $\mathrm{CH}_{4}$ production, while $\mathrm{O}_{3}$ pollution and $\mathrm{N}$ input indirectly influence $\mathrm{CH}_{4}$ oxidation through their impacts on ecosystem processes. The impacts of land conversion on $\mathrm{CH}_{4}$ flux could be caused by land-conversion-induced alterations in either substrate or environmental factors. It should be noted that the above equation solely summarizes the direct and indirect effects of multiple global change factors on $\mathrm{CH}_{4}$ processes; some other environmental factors which might influence $\mathrm{CH}_{4}$ processes were not included in this equation, for example, soil $\mathrm{pH}$, soil texture etc.

\subsection{Study area and input data}

North America was selected in this study. It includes United States of America (USA), Canada, and Mexico, covering a total area of approximately 24.71 million $\mathrm{km}^{2}$, about $4.8 \%$ of the planet's surface or $16.5 \%$ of its land area. Excluding water body and river, the North America consists of 21237 grids, at a spatial resolution of $32 \mathrm{~km} \times 32 \mathrm{~km}$, which is consistent with North American Regional Reanalysis (NARR) dataset. 
We developed gridded, geo-referenced, time-series input data sets of climate (including daily temperature, precipitation, humidity, and solar radiation), annual $\mathrm{N}$ deposition rate, annual land-cover change and land management practices (including fertilizer application, irrigation) for the entire continent. The climate dataset was generated based on NARR dataset (Mesinger et al., 2006). NARR data were provided by the NOAA/OAR/ESRL PSD, Boulder, Colorado, USA, from their Web site at http://www.esrl.noaa.gov/psd/. The maximum, minimum and average temperatures were calculated based on eight 3-h averages in one day. Precipitation, solar radiation, and relative humidity were directly derived from the NARR dataset. Land-use and land-cover change data were extracted from a global data set, History Database of the Global Environment (HYDE 3.0) (Klein and van Drecht, 2006). $\mathrm{O}_{3}$ pollution data was retrieved from a global dataset developed by Felzer et al. (2005). Annual $\mathrm{N}$ deposition data were retrieved from a global data set that was extrapolated from three yearly maps (Dentener et al., 2006). Soil property data, including soil texture, soil $\mathrm{pH}$, soil bulk density, were extracted from a global data set, Global Soil Data Task, which is posted online in the Oak Ridge National Laboratory Distributed Active Archive Center (www.daac.ornl.gov). Fertilizer application data for North America was developed by combining several data sources, including Food and Agriculture Organization (FAO) country-level data (www.fao.org), United State county-level data (www.usda.gov), and Canada provinciallevel data (www.cfi.ca). All the datasets were transformed and re-projected to one projection system for driving the DLEM. The annual atmospheric concentration of $\mathrm{CO}_{2}$ before 1959 was estimated by The Vegetation/Ecosystem Modeling and Analysis Project (VEMAP), and the data after 1959 were provided by National Oceanic and Atmospheric Administration (NOAA) (www.esrl.noaa.gov). The spatial distribution of potential vegetation types was developed using different sources of data, including global land-cover derived from Landsat imageries (De Fries et al., 1998), National Land Cover Dataset 2000 (www.usgs.gov), and global database of lakes, reservoirs and wetland (Lehner and Döll, 2004).

Historical data from 1901 to 2008 are prescribed as transient input data sets in this study. The transient input data include: (1) historical daily climate data from 1901 to 2008 including maximum, minimum and average temperatures, relative humidity, solar radiation, and precipitation; the data from 1901 to 1978 were randomly assigned as one year during 1979-2008; (2) historical annual N deposition from 1901 to 2008; (3) historical annual $\mathrm{O}_{3}$ pollution data from 1901 to 2008; (4) historical atmospheric $\mathrm{CO}_{2}$ concentration from 1901 to 2008; (5) historical cropland and urban distribution from 1901 to 2005; the land use since 2005 was assumed to be unchanged due to the shortage of data; and (6) historical $\mathrm{N}$ fertilizer application data for cropland for the time period of 1901-2008.

\subsection{Experimental design}

To determine the relative effects of $\mathrm{N}$ deposition, $\mathrm{O}_{3}$ pollution, climate variability, elevated atmospheric $\mathrm{CO}_{2}$, land-use change, and $\mathrm{N}$ fertilizer application on the terrestrial $\mathrm{CH}_{4}$ flux over North America, we conducted nineteen simulations in this study (Table 1). One overall simulation was set up to simulate the terrestrial $\mathrm{CH}_{4}$ flux over North America by considering the temporal and spatial dynamics of all six global change factors. Six more simulations were set up to simulate the effects of each individual factor on $\mathrm{CH}_{4}$ flux. For example, to determine the effects of climate variability alone, we ran DLEM using the gridded historical daily data for air temperature including maximum, minimum, and average air temperature, relative humidity, solar radiation, and precipitation, but kept all other five global change factors at the level in 1900: the atmospheric $\mathrm{CO}_{2}$ concentration, $\mathrm{N}$ deposition, $\mathrm{O}_{3}$ pollution, and $\mathrm{N}$ fertilizer application for cropland were kept constant at the level in 1900 and the land cover type in the year of 1900 (potential vegetation map with cropland and urban land in 1900). To determine the effects of $\mathrm{CO}_{2}$ fertilization alone, we ran DLEM using the historical atmospheric $\mathrm{CO}_{2}$ concentrations, but kept all other five global change factors constant: a 30-year average daily climate data was used to represent the constant climatic data and the potential vegetation map with crop and urban land in 1900 was used to represent the constant land cover type, $\mathrm{N}$ deposition, $\mathrm{O}_{3}$ pollution, and $\mathrm{N}$ fertilizer application data were kept constant in the year of 1900. For each of the above seven simulations, we set up one corresponding simulation which is the same as the previous simulation except the input data in 1979 was used to drive the post-1979 simulations; this design is used to capture the internal dynamics of the system which will serve as baseline.

Five more simulations were set up to separate the contributions from each single climate variable: precipitation, temperature (maximum, average, minimum), solar radiation, and relative humidity. Four simulations were set up to simulate the contribution from each of four climate variables, and one more was set up as baseline to exclude the contribution from system dynamics; i.e. the post-1979 simulations were fed by 1979 climate data (Table 1).

The implementation of DLEM simulation includes the following steps: (1) equilibrium run, (2) spinning-up run and (3) transient run. In this study, we first used potential vegetation map, long-term mean climate during 1979-2008, the concentration levels of $\mathrm{N}$ deposition, $\mathrm{O}_{3}$ pollution, atmospheric $\mathrm{CO}_{2}$ in the year of 1900 to drive the model run to an equilibrium state (i.e. the inter-annual variations are $<0.1 \mathrm{~g} \mathrm{~m}^{-2}$ for $\mathrm{C}$ storage and $<0.1 \mathrm{~g} \mathrm{~m}^{-2}$ for $\mathrm{N}$ storage). After the system reaches an equilibrium state, the model was run with an addition of cropland and urban areas for another 3000 years for spinning-up purposes. Finally, the model was run in transient mode with daily climate data, annual $\mathrm{CO}_{2}$ concentration and $\mathrm{N}$ deposition inputs from 1901 to 2008 to 
Table 1. Experimental design for this study.

\begin{tabular}{|c|c|c|c|c|c|c|}
\hline Simulation & Climate & Nitrogen deposition & $\mathrm{CO}_{2}$ & $\mathrm{O}_{3}$ & Nitrogen fertilizer & Land conversion \\
\hline 1 & 1900-2008 & 1900-2008 & 1900-2008 & 1900-2008 & 1900-2008 & 1900-2008 \\
\hline 2 & 1900-1979 & 1900-1979 & 1900-1979 & 1900-1979 & 1900-1979 & 1900-1979 \\
\hline 3 & 1900-2008 & 1900 & 1900 & 1900 & 1900 & 1900 \\
\hline 4 & 1900-1979 & 1900 & 1900 & 1900 & 1900 & 1900 \\
\hline 5 & 1900 & 1900-2008 & 1900 & 1900 & 1900 & 1900 \\
\hline 6 & 1900 & 1900-1979 & 1900 & 1900 & 1900 & 1900 \\
\hline 7 & 1900 & 1900 & 1900-2008 & 1900 & 1900 & 1900 \\
\hline 8 & 1900 & 1900 & 1900-1979 & 1900 & 1900 & 1900 \\
\hline 9 & 1900 & 1900 & 1900 & 1900-2008 & 1900 & 1900 \\
\hline 10 & 1900 & 1900 & 1900 & 1900-1979 & 1900 & 1900 \\
\hline 11 & 1900 & 1900 & 1900 & 1900 & 1900-2008 & 1900 \\
\hline 12 & 1900 & 1900 & 1900 & 1900 & 1900-1979 & 1900 \\
\hline 13 & 1900 & 1900 & 1900 & 1900 & 1900 & 1900-2008 \\
\hline 14 & 1900 & 1900 & 1900 & 1900 & 1900 & 1900-1979 \\
\hline & $\begin{array}{l}\text { Climate } \\
\text { (Precipitation) }\end{array}$ & $\begin{array}{l}\text { Climate (Maximum, } \\
\text { average, minimum } \\
\text { temperature) }\end{array}$ & $\begin{array}{l}\text { Solar } \\
\text { radiation }\end{array}$ & $\begin{array}{l}\text { Relative } \\
\text { humidity }\end{array}$ & \multicolumn{2}{|c|}{$\begin{array}{c}\text { Nitrogen deposition, } \mathrm{CO}_{2}, \mathrm{O}_{3}, \\
\text { nitrogen fertilizer, } \\
\text { and land conversion }\end{array}$} \\
\hline 15 & 1900-2008 & 1900-1979 & 1900-1979 & 1900-1979 & \multicolumn{2}{|c|}{1900} \\
\hline 16 & 1900-1979 & $1900-2008$ & 1900-1979 & 1900-1979 & \multicolumn{2}{|c|}{1900} \\
\hline 17 & 1900-1979 & 1900-1979 & 1900-2008 & 1900-1979 & \multicolumn{2}{|c|}{1900} \\
\hline 18 & 1900-1979 & 1900-1979 & 1900-1979 & 1900-2008 & \multicolumn{2}{|c|}{1900} \\
\hline 19 & 1900-1979 & 1900-1979 & 1900-1979 & 1900-1979 & \multicolumn{2}{|c|}{1900} \\
\hline
\end{tabular}

Note: the time period of 1900-2008 indicates that the data for the time period of 1900-2008 was used in the simulation; while the time period of 1900-1979 indicates that the data for the time period of 1900-1979 was used in the simulations, and the simulations after 1979 was fed by the data of 1979 .

Table 2. Changing rates of driving factors for DLEM simulations.

\begin{tabular}{cll}
\hline Variables & & $\begin{array}{l}\text { Changing rates } \\
(\text { Mean } \pm \mathrm{SD})\end{array}$ \\
\hline \multirow{6}{*}{ Climate } & Maximum temperature $\left({ }^{\circ} \mathrm{C} \mathrm{a}^{-1}\right)$ & $0.04 \pm 0.01^{*}$ \\
& Minimum temperature $\left({ }^{\circ} \mathrm{C} \mathrm{a}^{-1}\right)$ & $0.03 \pm 0.01^{*}$ \\
& Average temperature $\left({ }^{\circ} \mathrm{C} \mathrm{a}^{-1}\right)$ & $0.03 \pm 0.01^{*}$ \\
& Precipitation $\left(\mathrm{mm} \mathrm{a}^{-1}\right)$ & $0.65 \pm 0.65$ \\
& Relative humidity $\left(\% \mathrm{a}^{-1}\right)$ & $-0.01 \pm 0.01$ \\
& Solar radiation $\left(\mathrm{W} \mathrm{m}^{-2} \mathrm{a}^{-1}\right)$ & $0.17 \pm 0.03^{*}$ \\
\hline \multirow{3}{*}{ Others } & $\mathrm{O}_{3}$ pollution $\left(\mathrm{ppm}^{-1} \mathrm{hr} \mathrm{a}^{-1}\right)$ & $0.93 \pm 0.09^{*}$ \\
& $\mathrm{~N}$ deposition $\left(\mathrm{mg} \mathrm{m}^{-2} \mathrm{a}^{-1}\right)$ & $1.98 \pm 0.12^{*}$ \\
& $\mathrm{~N}$ fertilizer application $\left(\mathrm{mg} \mathrm{m}^{-2} \mathrm{a}^{-1}\right)$ & $0.06 \pm 0.01^{*}$ \\
& Atmospheric $\mathrm{CO}_{2}$ concentration $\left(\mathrm{ppm} \mathrm{a}^{-1}\right)$ & $1.66 \pm 0.02^{*}$ \\
\hline
\end{tabular}

* Indicates the changing rate is significantly different from zero; positive values represent increase through the study period, and negative values represent decrease through the study period. simulate $\mathrm{CH}_{4}$ flux. Only the outputs between 1979 and 2008 were analyzed to show the spatial and temporal patterns of $\mathrm{CH}_{4}$ flux in North America's terrestrial ecosystems. Urban was treated as grassland, which is the same as in the other terrestrial biosphere models (McGuire et al., 2001). Baseline flux was defined as the $\mathrm{CH}_{4}$ flux during 1979-2008 simulated by DLEM driven by the input data of 1979; the changes thereafter comparing to baseline flux was assumed solely caused by global change factors, individually or in combinations.

\subsection{Model parameterization and validation}

The model parameterization and validation at both site and regional levels have been conducted in our previous study (Tian et al., 2010a); the same parameter sets were used in this study. We will not describe them in detail here.

\subsection{Statistical analysis}

The regression analysis was used in this study to find the long-term changing rates of input data and $\mathrm{CH}_{4}$ fluxes generated by various simulations. All the statistical analyses were conducted by using the software SAS 9.2 and SPSS 17.0 for Windows XP. 
Table 3. Land area of the major biomes in North America.

\begin{tabular}{llllllll}
\hline Plant functional type & Tundra & Forest & Shrub & Grassland & Wetland & Desert and others & Cropland \\
\hline Area $\left(\right.$ million $\left.\mathrm{km}^{2}\right)$ & 4.05 & $6.93 \sim 6.99$ & $3.57 \sim 3.59$ & $2.61 \sim 2.64$ & $2.06 \sim 2.07$ & $0.53 \sim 0.60$ & $2.51 \sim 2.59$ \\
Percentage & 18.09 & 31.10 & 15.98 & 11.72 & 9.23 & 2.49 & 11.39 \\
\hline
\end{tabular}

Note: biome-level areas may not sum to totals because of the effects of rounding in reporting those values.

\section{Results}

\subsection{Spatial and temporal patterns of driving forces during 1979-2008}

Regression analysis was performed to estimate the temporal patterns of major input variables during 1979-2008 (Tables 2, 3). For the climatic variables, maximum, minimum, and average temperatures, and solar radiation showed significantly increasing rates of $0.04 \pm 0.01{ }^{\circ} \mathrm{C} \mathrm{a}^{-1}, 0.03 \pm$ $0.01^{\circ} \mathrm{Ca}^{-1}, 0.03 \pm 0.01^{\circ} \mathrm{Ca}^{-1}$, and $0.17 \pm 0.03 \mathrm{~W} \mathrm{~m}^{-2} \mathrm{a}^{-1}$, respectively; yet precipitation and relative humidity did not show any significant change along the study period. All the other driving factors significantly increased since 1979; the long-term increasing rates were $0.93 \pm 0.09 \mathrm{ppm}^{-\mathrm{hr} \mathrm{a}^{-1}}$ for $\mathrm{O}_{3}$ pollution, $1.98 \pm 0.12 \mathrm{mg} \mathrm{m}^{-2} \mathrm{a}^{-1}$ for $\mathrm{N}$ deposition, $0.06 \pm 0.01 \mathrm{~g} \mathrm{~m}^{-2} \mathrm{a}^{-1}$ for $\mathrm{N}$ fertilizer application, and $1.66 \pm$ $0.02 \mathrm{ppma}^{-1}$ for atmospheric $\mathrm{CO}_{2}$ concentration, respectively. The area of different land cover types changed slightly through the study period; for instance, the cropland area increased from 2.51 million $\mathrm{km}^{2}$ to 2.59 million $\mathrm{km}^{2}$; the areas of forest, shrub, grassland and wetland changed in very small magnitude. It should be noted that all above statistic were continental-level values; the changes in specific area or specific time period might be quite different.

Spatial variations of input data including potential vegetation distribution, $\mathrm{N}$ deposition, $\mathrm{N}$ fertilizer application rate, and $\mathrm{O}_{3}$ pollution were shown in Fig. 2. The Fig. 2a shows the contemporary spatial distribution of vegetation used in this study; it is noteworthy that natural wetlands primarily distribute in Alaska, western Canada, south to the Hudson Bay, eastern coastal area, and Florida in the USA (Fig. 2a). The severely $\mathrm{O}_{3}$-polluted area over North America locates in western part of North America such as the northwestern USA which could be as high as more than $5000 \mathrm{ppb}-\mathrm{hr}$ (monthly accumulated hourly $\mathrm{O}_{3}$ dose over a threshold of $40 \mathrm{ppb}$ in ppb-hr), while the other areas, especially northern end of continental North America, feature low $\mathrm{O}_{3}$ pollution (Fig. 2b). The major cropland with high $\mathrm{N}$ fertilizer application (larger than $10 \mathrm{~g} \mathrm{~N} \mathrm{~m}^{-2} \mathrm{a}^{-1}$ ) locates in USA, including western, central, and eastern costal area of USA. Canada and Mexico had small amount of cropland and received lower application rate of $\mathrm{N}$ fertilizer (Fig. 2c). The high $\mathrm{N}$ deposition primarily occurred in eastern part of the continental North America, including southeastern Canada, eastern USA and portions of Mexico (higher than $1 \mathrm{~g} \mathrm{~N} \mathrm{~m}^{-2} \mathrm{a}^{-1}$ ); while northern Canada features quite low $\mathrm{N}$ deposition (lower than $0.01 \mathrm{~g} \mathrm{~N} \mathrm{~m}^{-2} \mathrm{a}^{-1}$ ) (Fig. 2d).

\subsection{Spatial distribution of $\mathrm{CH}_{4}$ flux during 1979-2008}

The $\mathrm{CH}_{4}$ flux over the entire continent of North America showed substantial spatial variations (Fig. 3); the terrestrial ecosystems acted either as a source of atmospheric $\mathrm{CH}_{4}$ as high as more than $30 \mathrm{~g} \mathrm{C} \mathrm{m}^{-2} \mathrm{a}^{-1}$, or as a sink of atmospheric $\mathrm{CH}_{4}$ as high as $1 \mathrm{~g} \mathrm{C} \mathrm{m}^{-2} \mathrm{a}^{-1}$. A major source for atmospheric $\mathrm{CH}_{4}$ was found in northwestern part of North America, including southern part of Canada, western part of Canada, north central USA, southeastern USA, and Alaska; a strong sink for atmospheric $\mathrm{CH}_{4}$ was found in the southern part of the continental North America, including southern USA and most of Mexico; and other areas acted as a weak sink of atmospheric $\mathrm{CH}_{4}$.

\subsection{Factorial contributions to the spatial variation in terrestrial $\mathrm{CH}_{4}$ flux during 1979-2008}

In this study, we intended to examine the global change factor-induced changes in $\mathrm{CH}_{4}$ emission since 1979, so we assumed that the annual $\mathrm{CH}_{4}$ emission over North America during 1979-2008 with no driving forces changed is the baseline emission, and the changes in $\mathrm{CH}_{4}$ flux compared to the baseline flux are caused by individual and/or interactive effects of these global change factors. To quantify the factorial contributions to the spatial variations in terrestrial $\mathrm{CH}_{4}$ flux during 1979-2008, we first calculated the global change factor-induced $\mathrm{CH}_{4}$ flux by subtracting annual flux by the baseline flux, and then summed them up to reach the global change factor-induced $\mathrm{CH}_{4}$ flux over 30 years.

Over the past 30 years, climate variability enhanced $\mathrm{CH}_{4}$ emission in northwestern part of North America including western parts of Canada and northwestern USA, while decreased $\mathrm{CH}_{4}$ emission in northern, central, and southern parts of North America (Fig. 4a); $\mathrm{N}$ deposition enhanced $\mathrm{CH}_{4}$ emission across large area of North America, primarily in eastern parts of Canada, and southeastern US (Fig. 4b); elevated atmospheric $\mathrm{CO}_{2}$ enhanced $\mathrm{CH}_{4}$ emission over large area of continental North America yet did not yield significant impacts on southwestern US and majority of Mexico (Fig. 4c); $\mathrm{O}_{3}$ pollution exerted no significant effects on $\mathrm{CH}_{4}$ flux across majority of North America, while decreased 
A

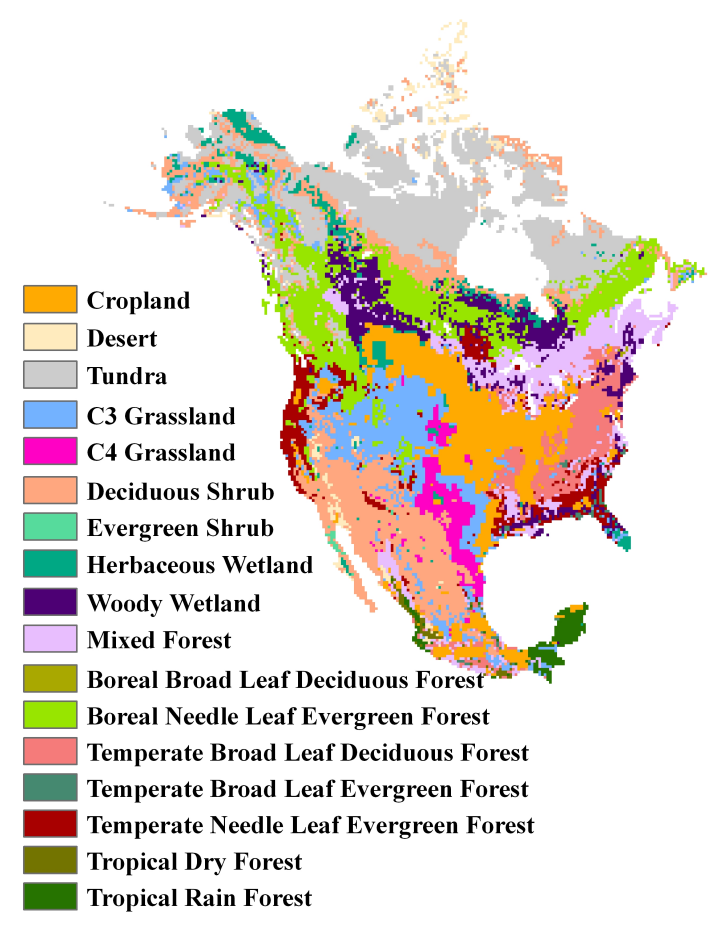

C

Nitrogen fertilizer application rate

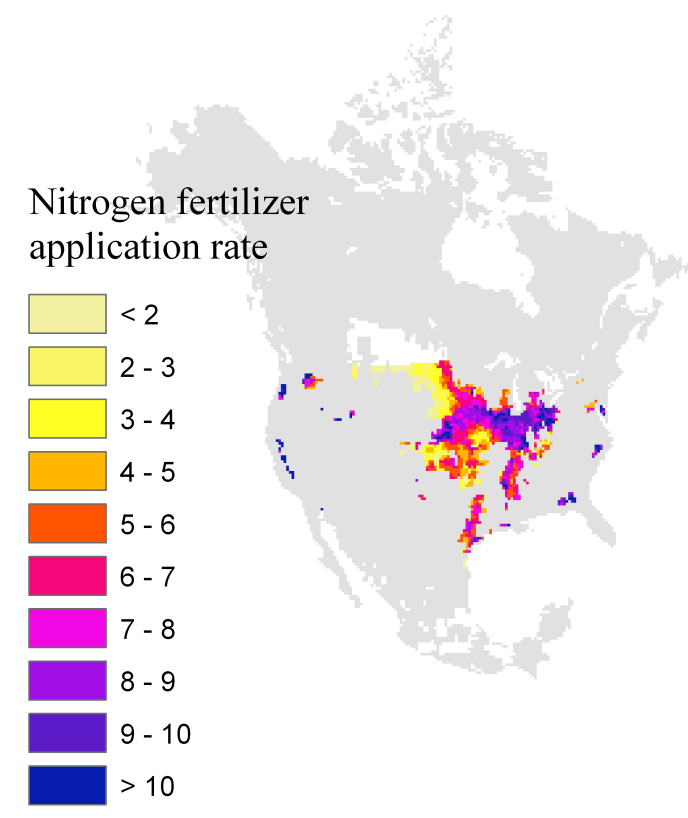

B

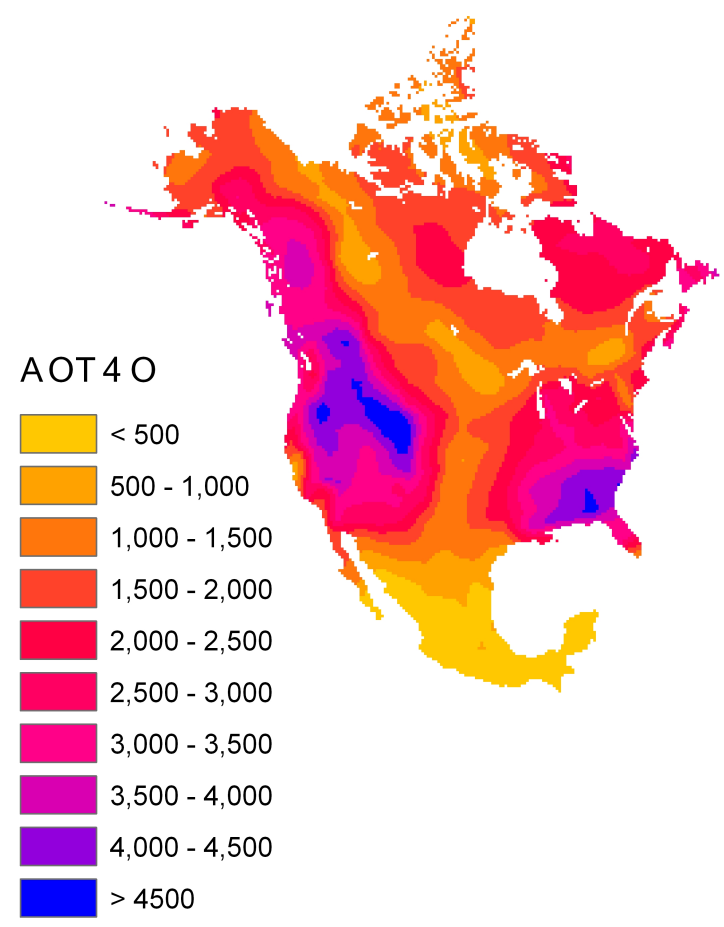

D

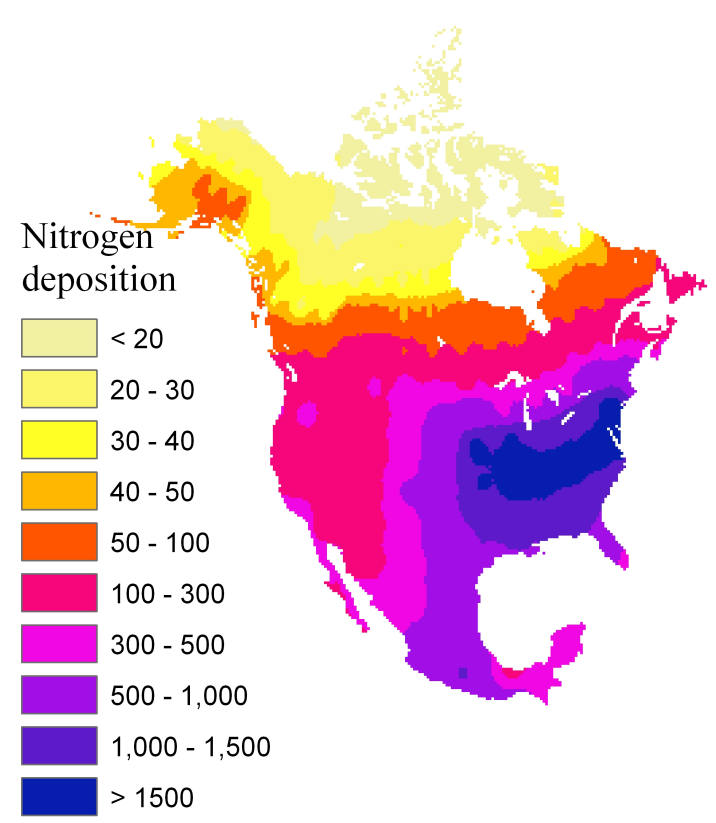

Fig. 2. (A) Contemporary vegetation map, and spatial distribution of 30-year averages of (B) monthly $\mathrm{O}_{3}$ pollution (ppb-hr), (C) $\mathrm{N}$ fertilizer application $\left(\mathrm{g} \mathrm{N} \mathrm{m}^{-2} \mathrm{a}^{-1}\right)$, and (D) $\mathrm{N}$ deposition rate $\left(\mathrm{mg} \mathrm{N} \mathrm{m}^{-2} \mathrm{a}^{-1}\right)$. 


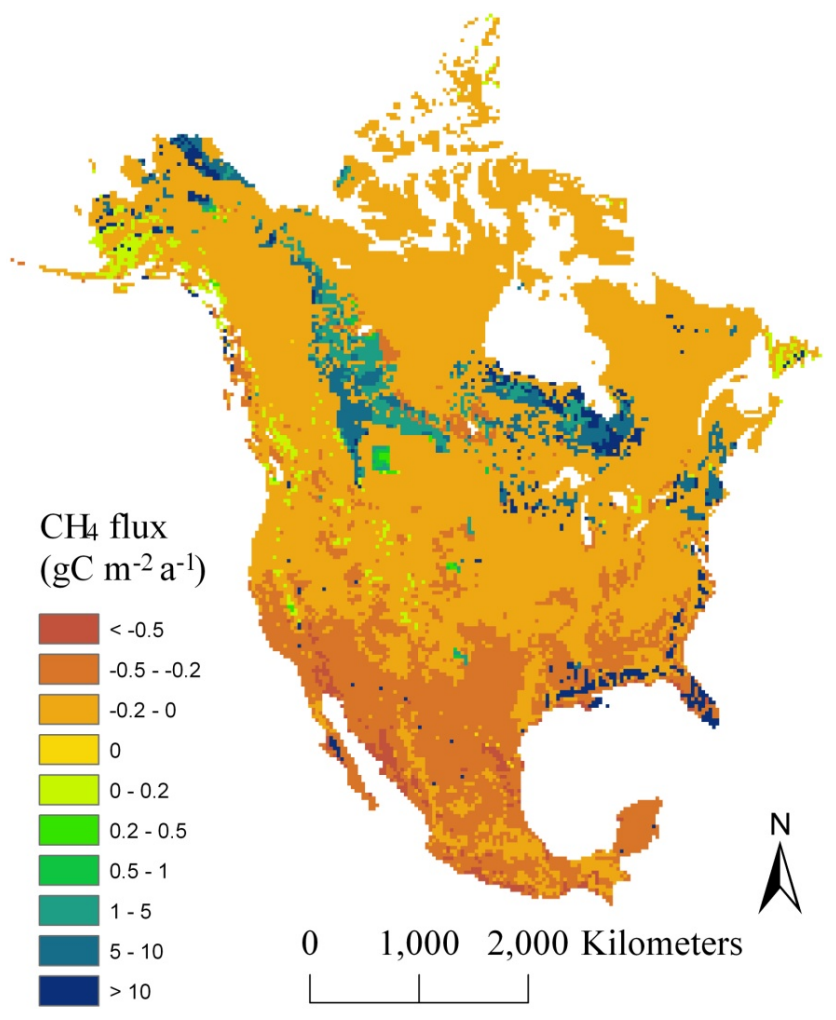

Fig. 3. Spatial variations of terrestrial $\mathrm{CH}_{4}$ fluxes caused by global change factors over North America from 1979 to 2008.

$\mathrm{CH}_{4}$ emission in southeastern parts of the continental North America and enhanced $\mathrm{CH}_{4}$ emission in small magnitude over portions of Canada (Fig. 4d); $\mathrm{N}$ fertilizer application and land conversion slightly enhanced $\mathrm{CH}_{4}$ emission in portions of agricultural land throughout North America (Fig. 4e and f); interactive effects between/among global change factors enhanced $\mathrm{CH}_{4}$ emission in large area of North America, especially the Southwest (Fig. 4h); combining all the effects from various global change factors, the $\mathrm{CH}_{4}$ emission over the western North America was enhanced over the past three decades, while portions of northern and central North America experienced the reduced $\mathrm{CH}_{4}$ emission (Fig. 4g).

\subsection{Temporal patterns of $\mathrm{CH}_{4}$ flux during 1979-2008}

The $\mathrm{CH}_{4}$ flux over the entire continental North America showed significant inter-annual fluctuations during 1979-2008 (Fig. 5). The lowest annual $\mathrm{CH}_{4}$ emission was $11.74 \mathrm{Tg} \mathrm{CH}_{4}-\mathrm{Ca}^{-1}$ in 1998 , and the highest was 18.42 $\mathrm{Tg} \mathrm{CH}_{4}-\mathrm{C} \mathrm{a}^{-1}$ in 2005. Before 2001, the $\mathrm{CH}_{4}$ flux did not show any significant change; however, since 2002 the $\mathrm{CH}_{4}$ emission rate increased dramatically, reached its peak in 2005, and decreased slightly since then. The mean annual $\mathrm{CH}_{4}$ flux over the past 30 years in North America's terrestrial ecosystems was $14.69 \pm 1.64 \mathrm{Tg} \mathrm{CH}_{4}-\mathrm{Ca}^{-1}$; and the overall increasing rate of $\mathrm{CH}_{4}$ flux was $0.10 \pm 0.03 \mathrm{~T} \mathrm{~g} \mathrm{CH}_{4}-\mathrm{Ca}^{-1}$ over study period $(P=0.003)$ (Fig. 5a).
Various global change factors yielded significantly different effects on the long-term trends of continental $\mathrm{CH}_{4}$ flux during 1979-2008 (Fig. 5). Climate variability generated a substantially inter-annual variation in $\mathrm{CH}_{4}$ flux, with an increasing rate of $0.15 \pm 0.04 \mathrm{~T} \mathrm{~g} \mathrm{CH}_{4}-\mathrm{Ca}^{-1}(P=0.002)$ (Fig. 5b). The continuously rising atmospheric $\mathrm{CO}_{2}$ concentration kept accelerating $\mathrm{CH}_{4}$ emission at an overall increasing rate of $0.02 \pm 0.004 \mathrm{~T} \mathrm{~g} \mathrm{CH}_{4}-\mathrm{Ca}^{-1}(P<0.001)$ (Fig. 5d), while $\mathrm{O}_{3}$ pollution decreased $\mathrm{CH}_{4}$ emission at a rate of $0.01 \pm 0.001 \mathrm{Tg} \mathrm{CH}_{4}-\mathrm{Ca}^{-1}(P<0.001)$ (Fig. 5e). $\mathrm{N}$ deposition generated an increasing rate of $0.71 \pm 0.05 \mathrm{Gg} \mathrm{CH}_{4}$ $\mathrm{C} \mathrm{a}^{-1}\left(1 \mathrm{Gg}=10^{9} \mathrm{~g}\right)$ to continental-level $\mathrm{CH}_{4}$ emission $(P<$ 0.001 ) (Fig. 5c), while $\mathrm{N}$ fertilizer application alone did not exert any significant effects on $\mathrm{CH}_{4}$ flux at the continental scale (Fig. 5f). Land conversion increased the terrestrial $\mathrm{CH}_{4}$ emission over North America from 1979 to 1995, and then decreased it from 1996 to 2008 . Over the entire study period, a significantly increasing rate of $0.007 \pm 0.001 \mathrm{Tg} \mathrm{CH}_{4}$ $\mathrm{Ca}^{-1} \quad(P<0.001)$ was simulated for the terrestrial $\mathrm{CH}_{4}$ emission over North America in response to land conversion only (Fig. 5g). A statistically significant correlation was also found between climate-induced annual $\mathrm{CH}_{4}$ flux and the overall $\mathrm{CH}_{4}$ flux contributed from all factors during 1979$2008(P<0.001)$.

\subsection{Factorial contributions to the accumulated $\mathrm{CH}_{4}$ flux during 1979-2008 at continental and country levels}

To quantify the relative contributions from multiple global change factors to the $\mathrm{CH}_{4}$ flux over North America during 1979-2008, we summed up the individual global change factor-induced changes in $\mathrm{CH}_{4}$ flux over 30 years to analyze the contributions of six single factors and their interaction. To express the uncertainties associated with the accumulated $\mathrm{CH}_{4}$ flux caused by six individual factors and their interaction, we treated the thirty annual fluxes as a sample to calculate the average flux and its standard error. Finally, the 30 -year accumulated flux and its standard error over study period were reported. Through the 30-year study period, the accumulated continental $\mathrm{CH}_{4}$ flux over North America was $440.75 \pm 8.97 \mathrm{~T} \mathrm{~g} \mathrm{CH}_{4}-\mathrm{C}$, of which 417.24 $\pm 6.83 \mathrm{~T} \mathrm{~g} \mathrm{CH}_{4}-\mathrm{C}$ was contributed from baseline flux and $23.51 \pm 9.61 \mathrm{~T}^{\mathrm{C} \mathrm{CH}} 4_{4}^{-}$ $\mathrm{C}$ was caused by global change factors (Table 4). $\mathrm{O}_{3}$ pollution and the interactive effects between/among multiple factors decreased $\mathrm{CH}_{4}$ emission by $2.30 \pm 0.49 \mathrm{~T} \mathrm{~g} \mathrm{CH}_{4}-\mathrm{C}$ and $4.84 \pm 7.74 \mathrm{~T} \mathrm{~g} \mathrm{CH}_{4}-\mathrm{C}$, respectively, while all the other single factors increased $\mathrm{CH}_{4}$ emission from North America's terrestrial ecosystems (Fig. 6).

The 30-year accumulated $\mathrm{CH}_{4}$ emission was $214.89 \pm$ $3.19 \mathrm{Tg} \mathrm{CH}_{4}-\mathrm{C}$ for USA and $230.47 \pm 8.72 \mathrm{~T} \mathrm{~g} \mathrm{CH}_{4}-\mathrm{C}$ for Canada, respectively. Mexico acted as a sink for atmospheric $\mathrm{CH}_{4}$, and the accumulative sink strength was $4.62 \pm$ $0.19 \mathrm{Tg} \mathrm{CH}_{4}-\mathrm{C}$ over the past 30 years (Table 4). For USA, climate variability and $\mathrm{O}_{3}$ pollution accumulatively decreased $\mathrm{CH}_{4}$ emission by $3.49 \pm 9.33 \mathrm{Tg} \mathrm{CH}_{4}-\mathrm{C}$ and $2.06 \pm$ 
A

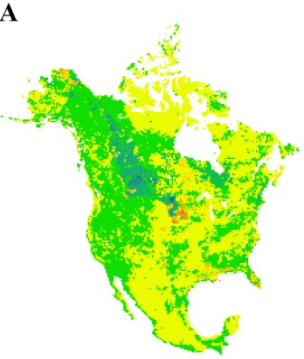

$\mathbf{E}$

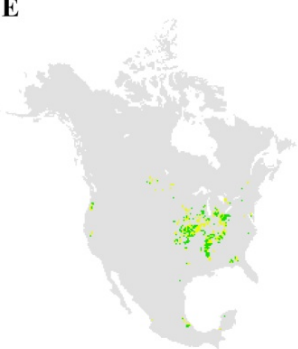

B

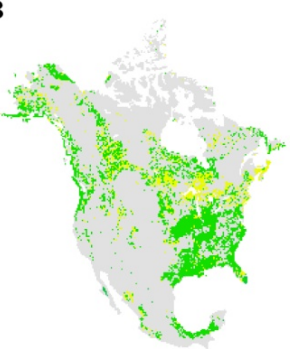

F

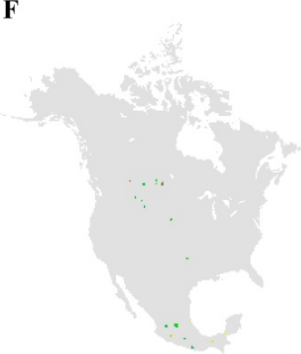

C

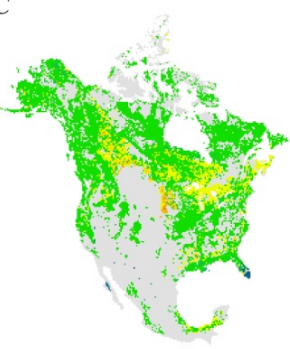

G

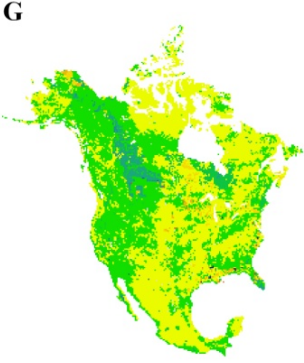

D

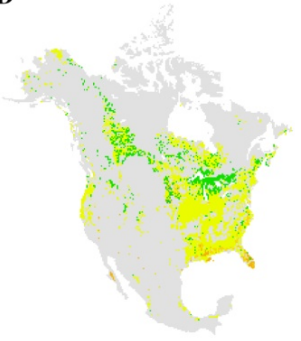

H

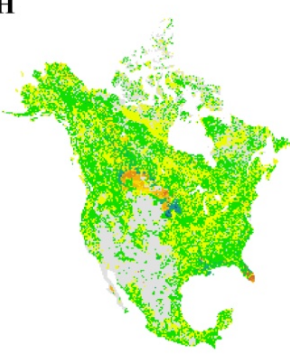

Accumulative $\mathrm{CH}_{4}\left(\mathrm{~g} \mathrm{C} \mathrm{m}^{-2}\right)$

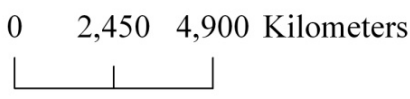

Fig. 4. Factorial contributions to the spatial variations in accumulated $\mathrm{CH}_{4}$ flux over North America from 1979 to 2008 ((A): climatic variability; (B): $\mathrm{N}$ deposition; $(\mathbf{C})$ : $\mathrm{CO}_{2} ;(\mathbf{D})$ : $\mathrm{O}_{3}$ pollution; $(\mathbf{E})$ : $\mathrm{N}$ fertilizer application; $(\mathbf{F})$ : land conversion; $(\mathbf{G})$ : all combined; $(\mathbf{H})$ : interaction).

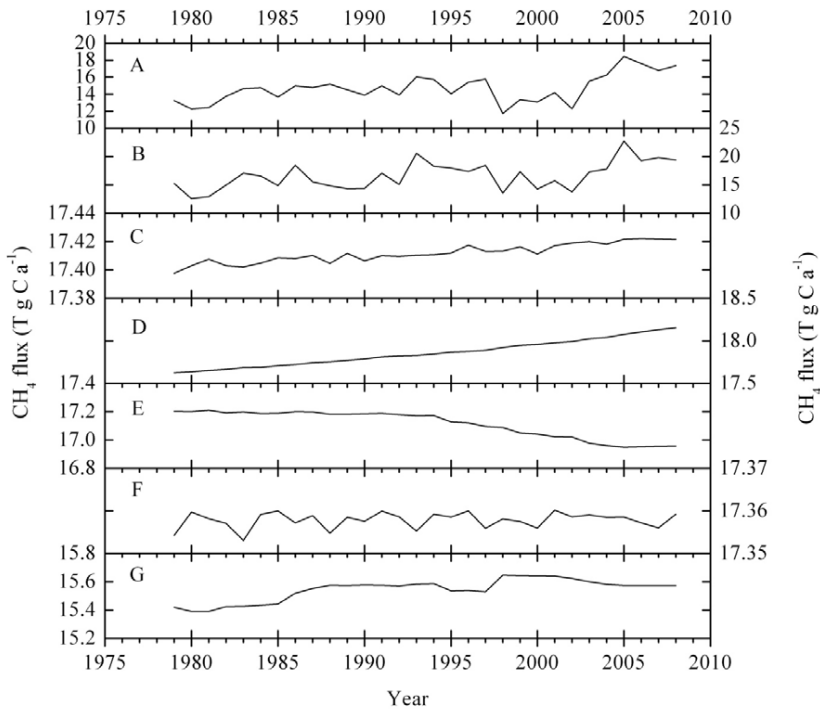

Fig. 5. Temporal variations of terrestrial $\mathrm{CH}_{4}$ flux caused by global change factors over North America from 1979 to 2008 ((A): all combined simulation; (B): climate only simulation; (C): $\mathrm{N}$ deposition only simulation; (D): $\mathrm{CO}_{2}$ only simulation; (E): $\mathrm{O}_{3}$ only simulation; $(\mathbf{F})$ : $\mathrm{N}$ fertilizer application simulation; $(\mathbf{G})$ : land conversion only simulation).
0.44 T g CH $4-\mathrm{C}$, respectively, during 1979-2008, while $\mathrm{N}$ deposition, elevated atmospheric $\mathrm{CO}_{2}$ and $\mathrm{N}$ fertilizer application, and land conversion accumulatively enhanced $\mathrm{CH}_{4}$ emissions (Table 4). For Canada, it is estimated that climate variability accumulatively enhanced $\mathrm{CH}_{4}$ emission by $23.32 \pm 10.95 \mathrm{~T} \mathrm{~g} \mathrm{CH}_{4}-\mathrm{C}$ during 1979-2008, N deposition, $\mathrm{O}_{3}$ pollution, and $\mathrm{N}$ fertilizer application increased $\mathrm{CH}_{4}$ emission; while elevated atmospheric $\mathrm{CO}_{2}$, land conversion and multiple-factor interaction decreased $\mathrm{CH}_{4}$ emission (Table 4). All factors except elevated atmospheric $\mathrm{CO}_{2}$ are important for $\mathrm{CH}_{4}$ emission in Mexico; simulation results showed that the elevated atmospheric $\mathrm{CO}_{2}$ accumulatively decreased $\mathrm{CH}_{4}$ consumption by $1.74 \pm 0.20 \mathrm{~T} \mathrm{~g} \mathrm{CH}_{4}-\mathrm{C}$ in Mexico during 1979-2008 (Table 4). Precipitation made positive impacts on $\mathrm{CH}_{4}$ flux at continental and countrylevels. Relative humidity, solar radiation, temperature, and their interactions also exerted influences, positive or negative on $\mathrm{CH}_{4}$ flux (Table 5). Overall, the global change factors enhanced $\mathrm{CH}_{4}$ emission from USA and Canada, while decreased $\mathrm{CH}_{4}$ uptake from Mexico from 1979 to 2008 (Fig. 7).

For the continental and country-level accumulated $\mathrm{CH}_{4}$ fluxes over 30 years, the baseline emission made the biggest contribution; it accounted for $94.67 \%$ of the continental $\mathrm{CH}_{4}$ emission, and $97.78 \%, 92.34 \%$, and $123.61 \%$ of the $\mathrm{CH}_{4}$ fluxes in the USA, Canada, and Mexico (Table 4). 
Table 4. Factorial contributions to the accumulated $\mathrm{CH}_{4}$ from 1979 to 2008.

\begin{tabular}{|c|c|c|c|c|c|c|c|c|c|c|}
\hline & & Baseline & Climate & Ndep & $\mathrm{CO}_{2}$ & $\mathrm{O}_{3}$ & Nfer & Land conversion & Interaction & Total flux \\
\hline \multirow[t]{2}{*}{ US } & $\begin{array}{l}\text { Accumulated } \mathrm{CH}_{4} \\
\text { flux }(\mathrm{Tg} \mathrm{C})\end{array}$ & $210.13 \pm 2.41$ & $-3.49 \pm 9.33$ & $0.05 \pm 0.01$ & $5.59 \pm 0.69$ & $-2.06 \pm 0.44$ & $0.004 \pm 0.001$ & $5.36 \pm 0.50$ & $-0.69 \pm 6.90$ & $214.89 \pm 3.19$ \\
\hline & Percentage (\%) & 97.78 & -1.62 & 0.02 & 2.60 & -0.96 & 0.002 & 2.49 & -0.32 & 100 \\
\hline \multirow[t]{2}{*}{ Canada } & $\begin{array}{l}\text { Accumulated } \mathrm{CH}_{4} \\
\text { flux }(\mathrm{TgC})\end{array}$ & $212.82 \pm 6.72$ & $23.32 \pm 10.95$ & $0.001 \pm 0.003$ & $0.53 \pm 0.04$ & $-0.01 \pm 0.01$ & $0.001 \pm 0.0002$ & $-1.48 \pm 0.14$ & $-4.71 \pm 2.28$ & $230.47 \pm 8.72$ \\
\hline & Percentage (\%) & 92.34 & 10.12 & 0.0004 & 0.23 & -0.003 & 0.0004 & -0.64 & -2.04 & 100 \\
\hline \multirow[t]{2}{*}{ Mexico } & $\begin{array}{l}\text { Accumulated } \mathrm{CH}_{4} \\
\text { flux }(\mathrm{TgC})\end{array}$ & $-5.71 \pm 0.21$ & $0.003 \pm 0.30$ & $0.04 \pm 0.01$ & $1.74 \pm 0.20$ & $-0.24 \pm 0.05$ & $0.005 \pm 0.0003$ & $0.08 \pm 0.01$ & $-0.53 \pm 0.13$ & $-4.62 \pm 0.19$ \\
\hline & Percentage $(\%)$ & 123.61 & -0.07 & -0.80 & -37.64 & 5.19 & -0.10 & 1.64 & 11.44 & 100 \\
\hline \multirow[t]{2}{*}{$\begin{array}{l}\text { North } \\
\text { America }\end{array}$} & $\begin{array}{l}\text { Accumulated } \mathrm{CH}_{4} \\
\text { flux }(\mathrm{TgC})\end{array}$ & $417.24 \pm 6.83$ & $19.80 \pm 12.42$ & $0.09 \pm 0.02$ & $6.80 \pm 0.86$ & $-2.30 \pm 0.49$ & $0.01 \pm 0.001$ & $3.95 \pm 0.38$ & $-4.84 \pm 7.74$ & $440.75 \pm 8.97$ \\
\hline & Percentage $(\%)$ & 94.67 & 4.49 & 0.02 & 1.54 & -0.52 & 0.002 & 0.90 & -1.10 & 100 \\
\hline
\end{tabular}

Note: country- or individual factor-based estimates may not sum to totals because of the effects of rounding in reporting those estimates.

Combined represents the effects with all six factors being considered; the Baseline represents contribution from baseline emission; the Climate represents the impacts of climate variability only; Ndep represents the impacts of $\mathrm{N}$ deposition; $\mathrm{CO}_{2}$ represents the impacts of $\mathrm{CO}_{2}$ variation; $\mathrm{O}_{3}$ represents the impacts of $\mathrm{O}_{3}$ pollution; $\mathrm{Nfer}$ represents the impacts of $\mathrm{N}$ fertilizer application; Land conversion represents the impacts of land cover change only; Interaction represents the balance of all interactive effects of the six environmental factors; the positive values represent $\mathrm{CH}_{4}$ emission, while negative values represent $\mathrm{CH}_{4}$ uptake by terrestrial ecosystems.

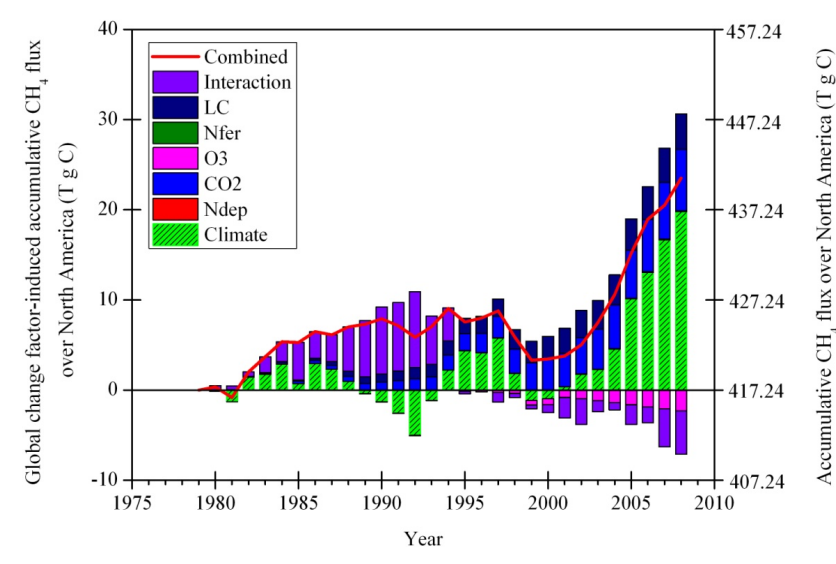

Fig. 6. Factorial contributions to accumulated $\mathrm{CH}_{4}$ flux over North America during 1979-2008 (The right Y-axis shows the accumulated $\mathrm{CH}_{4}$ flux with baseline; Interaction means contribution from multiple-factor interaction; LC means contribution from land conversion; Nfer means contribution from $\mathrm{N}$ fertilizer application; $\mathrm{O}_{3}$ means contribution from $\mathrm{O}_{3}$ pollution; $\mathrm{CO}_{2}$ means contribution from elevated atmospheric $\mathrm{CO}_{2}$; Ndep means contribution from $\mathrm{N}$ deposition; Climate means contribution from climate variability).

\subsection{Factorial contributions to the inter-annual varia- tions in $\mathrm{CH}_{4}$ flux during 1979-2008 at continental and country levels}

Inter-annual variation is one of major attributes of ecosystem processes; it may be caused by internal mechanisms or external environmental controls. Inter-annual variation in terrestrial $\mathrm{CH}_{4}$ has been shown over North America during 19792008 (Fig. 5). After removing the baseline emission of $\mathrm{CH}_{4}$, we identified the major factors for the year-by-year variation in $\mathrm{CH}_{4}$ flux (Fig. 8). Over the study period, climate variability and multiple-factor interaction played a predominant role in contributing to the inter-annual fluctuation in terrestrial $\mathrm{CH}_{4}$ flux (Fig. 8). Climate variability-induced effects dominated the increases in $\mathrm{CH}_{4}$ emission over four time periods: 1981-1984, 1993-1995, 1998-1999, and 2004-2008. Over the time period of 1987-1990, the interaction among multiple global change factors dominated the sink of atmospheric $\mathrm{CH}_{4}$. During other time periods, multiple-factor interaction also made significant contributions to the changes in $\mathrm{CH}_{4}$ flux although it did not dominate the inter-annual fluctuations in $\mathrm{CH}_{4}$ flux. Of the climate impacts on inter-annual variations in terrestrial $\mathrm{CH}_{4}$ fluxes, we further conducted multiple linear regressions to partition the contributions from each climate variable. All variables including precipitation, relative humidity, solar radiation, and temperature made significant contribution, with the largest contribution from precipitation.

After partitioning continental flux into country-level fluxes of $\mathrm{CH}_{4}$, we further analyzed and identified the major factors controlling the inter-annual fluctuations in terrestrial $\mathrm{CH}_{4}$ flux over each country. It is found that the major factors leading to inter-annual fluctuation in terrestrial $\mathrm{CH}_{4}$ flux varied across countries. Climate variability and multiple-factors interaction dominated the inter-annual fluctuations in terrestrial $\mathrm{CH}_{4}$ flux in USA; for instance, the climate variability dominated the sink of atmospheric $\mathrm{CH}_{4}$ over USA during the periods of 1988-1995; multiple-factor interaction dominated the sink of atmospheric $\mathrm{CH}_{4}$ over USA in the year of 2007 (Fig. 9a). Climate variability outweighed other factors in controlling the increases in terrestrial $\mathrm{CH}_{4}$ emission over Canada (Fig. 9b). Climate variability and interactive effect of multiple-factor affected the inter-annual fluctuations in terrestrial $\mathrm{CH}_{4}$ flux over Mexico; since 1996, although the elevated atmospheric $\mathrm{CO}_{2}$ outweighed other factors in contributing to the decrease in terrestrial $\mathrm{CH}_{4}$ consumption, climatic variability dominated the inter-annual fluctuation in $\mathrm{CH}_{4}$ flux over Mexico (Fig. 9c). Further analysis showed that all climate variables made significant contributions, with 
Table 5. Contributions from individual climate variable to the climate-induced $\mathrm{CH}_{4}$ accumulation (T g C) from 1979 to 2008 .

\begin{tabular}{lrrrrrr}
\hline & Precipitation & Relative humidity & Solar radiation & Temperature & Interaction & Total flux \\
\hline US & $14.99 \pm 8.26$ & $-5.30 \pm 6.71$ & $2.57 \pm 6.76$ & $0.55 \pm 6.66$ & $-16.30 \pm 20.54$ & $-3.49 \pm 9.33$ \\
Canada & $8.53 \pm 8.71$ & $-28.02 \pm 6.95$ & $-32.54 \pm 7.15$ & $-18.48 \pm 6.91$ & $93.82 \pm 21.90$ & $23.32 \pm 10.95$ \\
Mexico & $0.49 \pm 0.23$ & $0.81 \pm 0.22$ & $0.59 \pm 0.21$ & $-0.08 \pm 0.28$ & $-1.81 \pm 0.63$ & $0.003 \pm 0.30$ \\
North America & $24.01 \pm 10.08$ & $-32.51 \pm 9.01$ & $-29.38 \pm 9.45$ & $-18.01 \pm 9.00$ & $75.69 \pm 29.14$ & $19.8 \pm 12.42$ \\
\hline
\end{tabular}

Note: country- or individual factor-based estimates may not sum to totals because of the effects of rounding in reporting those estimates.

the largest contribution from precipitation in the USA, and Canada, and temperature in Mexico.

\section{Discussion}

\subsection{Comparisons with others}

Over the study period of 1979-2008, continental North America experienced significant environmental change (Wofsy and Harriss, 2002), which was also reflected in the input data for simulations in this study (Figs. 2, 3). These significant changes in environmental factors altered the regimes of terrestrial $\mathrm{CH}_{4}$ flux over North America at both temporal and spatial scales. Spatial heterogeneity in terrestrial $\mathrm{CH}_{4}$ flux is primarily determined by land use type over North America. The relatively high $\mathrm{CH}_{4}$ emission in northwestern continental North America is due to the dense distribution of natural wetland in that region (Fig. 2a) (Bridgham et al., 2006); the strong $\mathrm{CH}_{4}$ sink in the south part of continental North America is due to the tropical forests and high air temperature which are usually associated with high $\mathrm{CH}_{4}$ oxidation rate (Amaral et al., 1998; Curry, 2009; Ridgwell et al., 1999). The strong sources of $\mathrm{CH}_{4}$ in northeastern and southeastern US are consistent with Potter et al.'s study (Potter et al., 2006).

We also compared our model results against previous studies to verify our simulated factorial effects on $\mathrm{CH}_{4}$ flux for major biomes (Table 6). DLEM-derived continental-average response to elevated $\mathrm{CO}_{2}$ is a $58 \%$ increase in $\mathrm{CH}_{4}$ emission for wetland, which is close to the middle point of a previously reported range of $0 \sim 146 \%$, and is a $1 \%$ decrease in $\mathrm{CH}_{4}$ consumption for meadow grassland, which is comparable to Kanerva et al. (2007) result that shows a negative yet not significant effect of elevated atmospheric $\mathrm{CO}_{2}$ on $\mathrm{CH}_{4}$ consumption in a meadow ecosystem. Model-estimated results show that elevated atmospheric $\mathrm{CO}_{2}$ decreased $\mathrm{CH}_{4}$ consumption in temperate forest at a rate of $3 \%$, which is lower than $9 \sim 30 \%$ as reported from previous field studies (Phillips et al., 2001; Ambus and Robertson, 1999); this is probably due to one or several of three reasons: the scarcity of data in previous studies, preference to report unusual value in field experiments, and the different methods used in this research and other studies. The effects of $\mathrm{O}_{3}$ pollution on $\mathrm{CH}_{4}$ flux were comparable between our continental estimations and previous studies; both agreed that the $\mathrm{O}_{3}$ pollution exerted negative yet not significant effects on $\mathrm{CH}_{4}$ from peatland and meadow grassland (Table 6).

DLEM-derived $\mathrm{N}$ input effects on $\mathrm{CH}_{4}$ emission or uptake are quite consistent with previously summarized results in dry cropland. Model-estimated $\mathrm{N}$ deposition-induced $\mathrm{CH}_{4}$ emission is $7.43 \pm 1.09 \mathrm{mg} \mathrm{C} \mathrm{m}^{-2} \mathrm{a}^{-1}$ per $\mathrm{g} \mathrm{N}^{-1} \mathrm{~m}^{-2} \mathrm{a}^{-1}$ for dry cropland, comparing to $12 \pm 6 \mathrm{mg} \mathrm{C} \mathrm{m}^{-2} \mathrm{a}^{-1}$ per $\mathrm{g} \mathrm{N}^{-1} \mathrm{~m}^{-2} \mathrm{a}^{-1}$ summarized in Liu and Greaver's study (2009). However, it is fairly different between DELMestimated and summarized $\mathrm{N}$ input effects on $\mathrm{CH}_{4}$ flux for other biomes. For example, model-estimated $\mathrm{N}$ depositioninduced $\mathrm{CH}_{4}$ uptake is $-0.32 \pm 0.02 \mathrm{mg} \mathrm{C} \mathrm{m}^{-2} \mathrm{a}^{-1}$ per $\mathrm{g} \mathrm{N}^{-1} \mathrm{~m}^{-2} \mathrm{a}^{-1}$ for forest, compared to $17 \pm 5 \mathrm{mg} \mathrm{C} \mathrm{m}^{-2} \mathrm{a}^{-1}$ per $\mathrm{g} \mathrm{N}^{-1} \mathrm{~m}^{-2} \mathrm{a}^{-1}$ in Liu and Greaver's study (2009), and $-10.75 \pm 3.98\left(\mathrm{mg} \mathrm{C} \mathrm{m}^{-2} \mathrm{a}^{-1}\right.$ per $\left.\mathrm{g} \mathrm{N}^{-1} \mathrm{~m}^{-2} \mathrm{a}^{-1}\right)$ in $\mathrm{CH}_{4}$ uptake in a field experiment (Steudler et al., 1989). It should be noted that the changes in $\mathrm{CH}_{4}$ flux result from net changes in $\mathrm{CH}_{4}$ production and consumption; for example the increases in $\mathrm{CH}_{4}$ emission might result from either increases in $\mathrm{CH}_{4}$ production or decreases in $\mathrm{CH}_{4}$ consumption; the increases in $\mathrm{CH}_{4}$ uptake might result from either increases in $\mathrm{CH}_{4}$ oxidation or decreases in $\mathrm{CH}_{4}$ production; Liu and Greaver's study solely reported production or uptake (2009), while this study reported the net flux from production, oxidation, and transport (Materials and methods section).

The differences in model-estimated and summarized $\mathrm{N}$ effects on $\mathrm{CH}_{4}$ flux in forests might be due to a few reasons: the missing mechanisms in our model, lacking of field observations in summarization, or the different methods in two studies. $\mathrm{N}$ restrain on methanotrophy, long been identified as one of the most important mechanisms for the effects of $\mathrm{N}$ impact on $\mathrm{CH}_{4}$ flux (Dunfield and Knowles, 1995; Schnell and King, 1994; Bosse et al., 1993; Nold et al., 1999), was not included in our model; this might need to be improved in future work. The shortage of field observation has long been identified as one of the biases in summarization for scientific induction (Tian et al., 1998; Schimel et al., 2000). The different methods used in our study and Liu and Greaver's study might explain the difference between two studies; our study actually cover all the area of same biome type across 

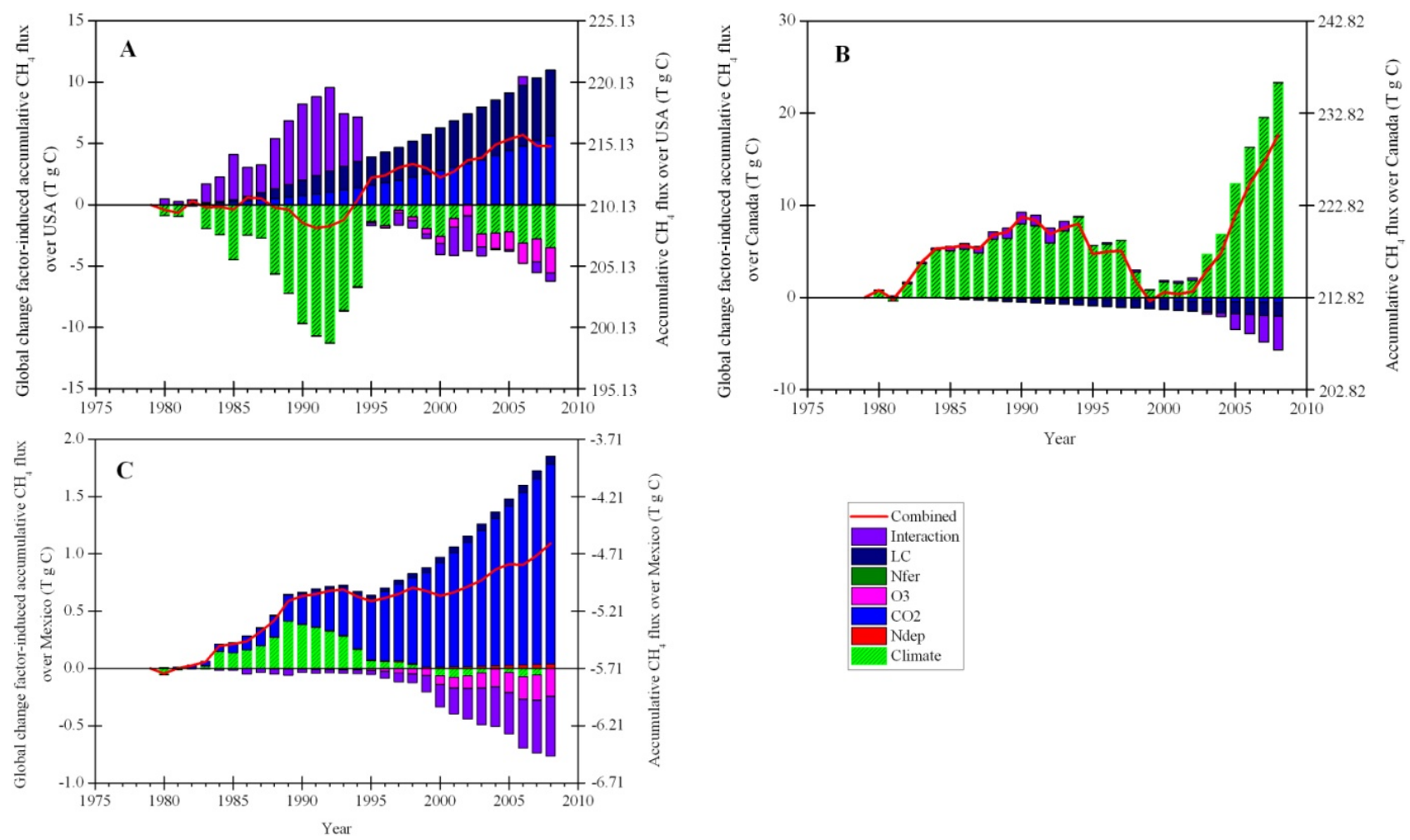

Fig. 7. Factorial contributions to accumulated $\mathrm{CH}_{4}$ flux at country-level during 1979-2008 ((A): USA; (B): Canada; (C): Mexico) (The right Y-axis shows the accumulated $\mathrm{CH}_{4}$ flux with baseline; Interaction means contribution from multiple-factor interaction; LC means contribution from land conversion; Nfer means contribution from $\mathrm{N}$ fertilizer application; $\mathrm{O}_{3}$ means contribution from $\mathrm{O}_{3}$ pollution; $\mathrm{CO}_{2}$ means contribution from elevated atmospheric $\mathrm{CO}_{2}$; Ndep means contribution from $\mathrm{N}$ deposition; Climate means contribution from climate variability).

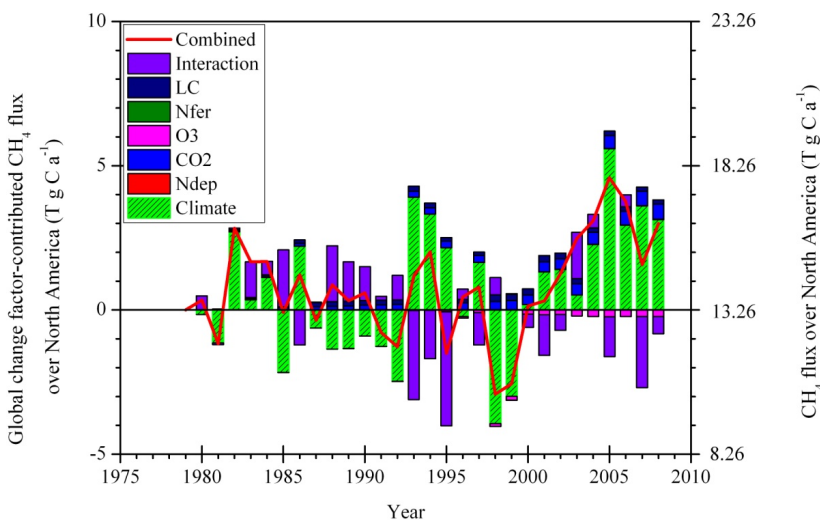

Fig. 8. Factorial contribution to the inter-annual variations in $\mathrm{CH}_{4}$ flux over North America (The right Y-axis shows the accumulated $\mathrm{CH}_{4}$ flux with baseline; Interaction means contribution from multiple-factor interaction; LC means contribution from land conversion; Nfer means contribution from $\mathrm{N}$ fertilizer application; $\mathrm{O}_{3}$ means contribution from $\mathrm{O}_{3}$ pollution; $\mathrm{CO}_{2}$ means contribution from elevated atmospheric $\mathrm{CO}_{2}$; Ndep means contribution from $\mathrm{N}$ deposition; Climate means contribution from climate variability).
North America, while Liu and Greaver's study only contain few data points across the globe, even rarer for North America. Given the large $\mathrm{CH}_{4}$ flux and $\mathrm{N}$ limitation for most of the wetland ecosystems (LeBauer and Treseder, 2008; Morris, 1991), a small amount of $\mathrm{N}$ input might significantly stimulate $\mathrm{CH}_{4}$ emission (Zhang et al., 2007b). DLEMestimated $\mathrm{N}$ input effect on $\mathrm{CH}_{4}$ emission in wetlands is $272 \pm 15 \mathrm{mg} \mathrm{C} \mathrm{m}^{-2} \mathrm{a}^{-1}$ per $\mathrm{g} \mathrm{N}^{-1} \mathrm{~m}^{-2} \mathrm{a}^{-1}$ compared to $8 \pm$ $4 \mathrm{mg} \mathrm{C} \mathrm{m}^{-2} \mathrm{a}^{-1}$ per $\mathrm{g} \mathrm{N}^{-1} \mathrm{~m}^{-2} \mathrm{a}^{-1}$ in Liu and Greaver's study (2009) and $676 \mathrm{mg} \mathrm{C} \mathrm{m}^{-2} \mathrm{a}^{-1}$ per $\mathrm{g} \mathrm{N}^{-1} \mathrm{~m}^{-2} \mathrm{a}^{-1}$ in a field experiment (Zhang et al., 2007c). The effects from climate variability and land conversion are more dependent on driving data; we assumed our results are reliable in simulating effects of land conversion and climate change on $\mathrm{CH}_{4}$ flux as our model works fairly well in estimating absolute flux of $\mathrm{CH}_{4}$ in most biomes in response to climate variability and other driving forces (Tian et al., 2010a).

Model-estimated $\mathrm{N}$ deposition-induced $\mathrm{CH}_{4}$ uptake is $-0.21 \pm 0.02 \mathrm{mg} \mathrm{C} \mathrm{m}^{-2} \mathrm{a}^{-1}$ per $\mathrm{g} \mathrm{N}^{-1} \mathrm{~m}^{-2} \mathrm{a}^{-1}$ for grassland comparing to $0 \mathrm{mg} \mathrm{C} \mathrm{m}^{-2} \mathrm{a}^{-1}$ per $\mathrm{g} \mathrm{N}^{-1} \mathrm{~m}^{-2} \mathrm{a}^{-1}$ in Liu and Greaver's study (2009). DLEM-estimated decrease in $\mathrm{CH}_{4}$ uptake in response to $\mathrm{N}$ input is due to $\mathrm{N}$ induced decrease in $\mathrm{CH}_{4}$ oxidation (Nold et al., 1999). The reported null 

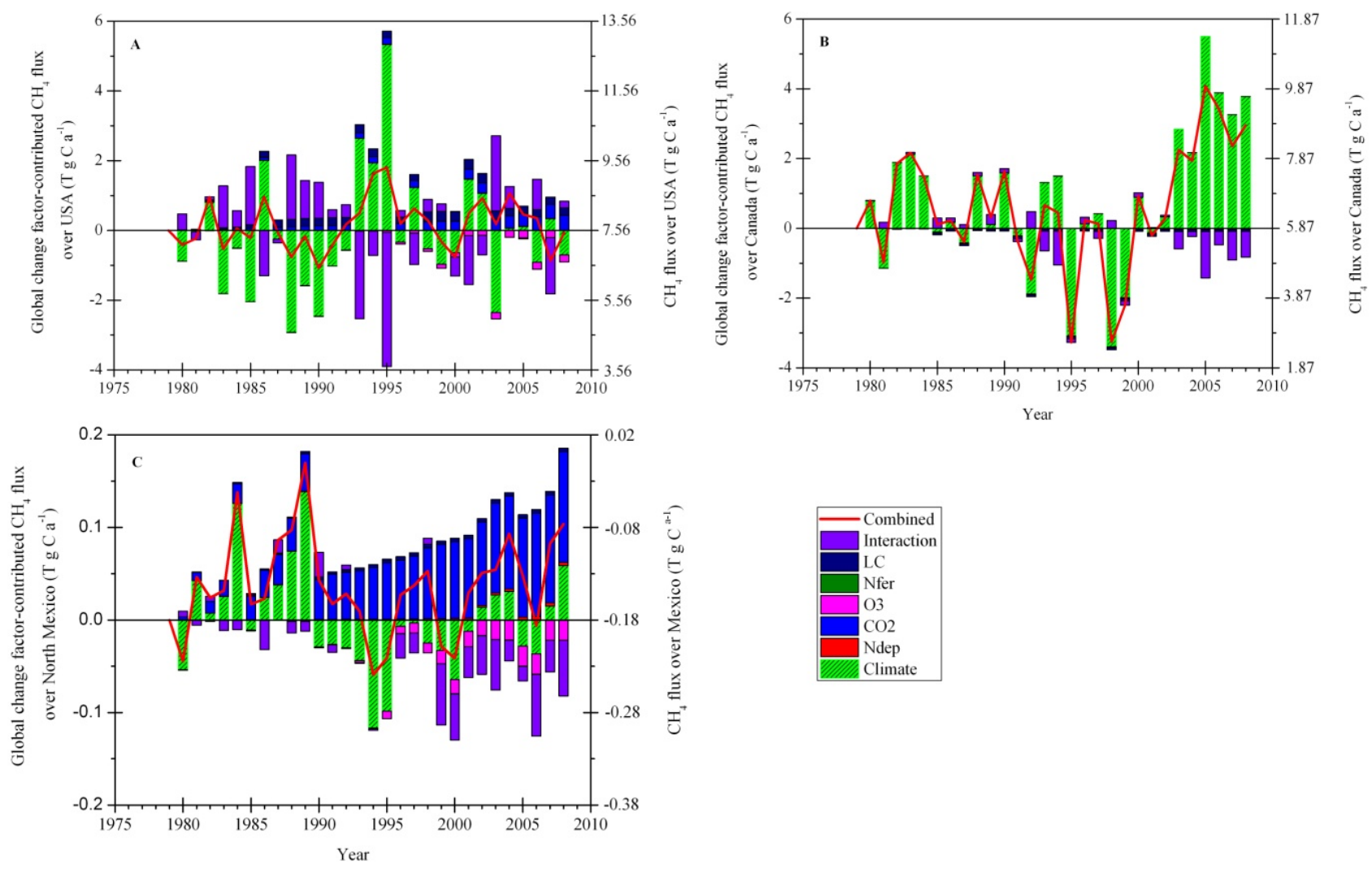

Fig. 9. Factorial contribution to the inter-annual variations in $\mathrm{CH}_{4}$ flux by country ((A): USA; (B): Canada; (C): Mexico) (The right Y-axis shows the accumulated $\mathrm{CH}_{4}$ flux with baseline; Interaction means contribution from multiple-factor interaction; LC means contribution from land conversion; Nfer means contribution from $\mathrm{N}$ fertilizer application; $\mathrm{O}_{3}$ means contribution from $\mathrm{O}_{3}$ pollution; $\mathrm{CO}_{2}$ means contribution from elevated atmospheric $\mathrm{CO}_{2}$; Ndep means contribution from $\mathrm{N}$ deposition; Climate means contribution from climate variability).

response of $\mathrm{CH}_{4}$ flux in grassland in response to $\mathrm{N}$ input in Liu and Greaver's study might be due to lack of observations (2009).

\subsection{Factorial controls on $\mathrm{CH}_{4}$ flux}

The enhancements of $\mathrm{CH}_{4}$ emission by $\mathrm{N}$ input, including atmospheric deposition and anthropogenic fertilizer application, and elevated atmospheric $\mathrm{CO}_{2}$ concentration are possibly due to the higher substrate caused by higher net primary production in response to elevated atmospheric $\mathrm{CO}_{2}$ and $\mathrm{N}$ input (Magnani et al., 2007; Reich et al., 2001, 2006); the continental-average $\mathrm{N}$ deposition has increased from $0.28 \mathrm{~g} \mathrm{~N} \mathrm{~m}^{-2} \mathrm{a}^{-1}$ in 1979 to $0.39 \mathrm{~g} \mathrm{~N} \mathrm{~m}^{-2} \mathrm{a}^{-1}$ in 2008; and $\mathrm{N}$ fertilizer application rate has increased from $4.92 \mathrm{~g} \mathrm{~N} \mathrm{~m}^{-2} \mathrm{a}^{-1}$ in 1979 to $6.92 \mathrm{~g} \mathrm{~N} \mathrm{~m}^{-2} \mathrm{a}^{-1}$ in 2007; $\mathrm{O}_{3}$ pollution decreased $\mathrm{CH}_{4}$ emission over North America, in the USA and Canada which is probably due to the negative effect posed by $\mathrm{O}_{3}$ on plant (Morsky et al., 2008). The effects of land conversion on $\mathrm{CH}_{4}$ emission really depends on the direction of land conversion, if the conversion is from wetland to other ecosystem types, the $\mathrm{CH}_{4}$ emission will definitely decrease (Inubushi et al., 2003; Jiang et al., 2009).

\subsection{Inter-annual variability in $\mathrm{CH}_{4}$ flux}

The overall increases in terrestrial $\mathrm{CH}_{4}$ emission over North America caused by global change factors could be primarily attributed to climate variability during 1979-2008 (Fig. 6). This indicates a potential increase in atmospheric $\mathrm{CH}_{4}$ concentration resulted from accelerating $\mathrm{CH}_{4}$ emission from terrestrial ecosystem under the future climate change projected by many general circulation models (Forster et al., 2007).

The inter-annual variability in the continental $\mathrm{CH}_{4}$ flux was dominated by climatic variability (Table 3 ); this would be supported by the significantly positive correlation between climate-induced and overall $\mathrm{CH}_{4}$ fluxes (Fig. 4), and the detailed analysis of factorial contribution to terrestrial $\mathrm{CH}_{4}$ flux over the 30 years (Fig. 6). Meanwhile, the long-term trend of $\mathrm{CH}_{4}$ flux was also contributed from rising atmospheric $\mathrm{CO}_{2}$ concentration, $\mathrm{N}$ deposition, $\mathrm{O}_{3}$ pollution, $\mathrm{N}$ fertilizer application, and land conversion. The climate variability increased $\mathrm{CH}_{4}$ emission from North American terrestrial ecosystems; this is primarily resulted from the climatic effects on $\mathrm{CH}_{4}$ emission over Canada. The increased temperature are primarily occurred in Canada, given that the temperature sensitivity of soil organic matter decomposition is 
Table 6. Comparison of factorial effects on $\mathrm{CH}_{4}$ fluxes against other studies (positive values mean increase, while negative values mean decrease, either in $\mathrm{CH}_{4}$ uptake or in $\mathrm{CH}_{4}$ emission).

\begin{tabular}{|c|c|c|c|c|c|}
\hline & Biome & Experiment design & This study & Others & Reference \\
\hline \multirow{3}{*}{$\begin{array}{l}\text { Elevated } \mathrm{CO}_{2} \\
\text { concentration }\end{array}$} & $\begin{array}{l}\text { Mire, } \\
\text { wetland }\end{array}$ & $\begin{array}{l}\text { Double } \mathrm{CO}_{2} \text { or } 200 \\
\text { ppm increase from } \\
355 \mathrm{ppm} \text { to } 550 \mathrm{ppm}\end{array}$ & $+58 \%$ in $\mathrm{CH}_{4}$ emission* & $0 \sim+146 \%$ in $\mathrm{CH}_{4}$ emission & $\begin{array}{l}\text { Saarnio and Silvola (1999); Megonigal and } \\
\text { Schlesinger (1997); Cheng et al. (2006); } \\
\text { Dacey et al. (1994); Saarnio et al. (1998); } \\
\text { Silvola et al. (2003); Vann and Megonigal } \\
\text { (2003); Hutchin et al. (1995) }\end{array}$ \\
\hline & $\begin{array}{l}\text { Temperate } \\
\text { forest }\end{array}$ & $\begin{array}{l}360 \text { ppm rose to } 560 \\
\text { ppm of atmospheric } \\
\mathrm{CO}_{2}\end{array}$ & $\begin{array}{l}-3 \% \text { in } \mathrm{CH}_{4} \\
\text { consumption** }\end{array}$ & $\begin{array}{l}-9 \sim-30 \% \text { in } \mathrm{CH}_{4} \\
\text { consumption }\end{array}$ & $\begin{array}{l}\text { Phillips et al. (2001); Ambus and Robertson } \\
\text { (1999) }\end{array}$ \\
\hline & meadow & $\begin{array}{l}+100 \text { ppm increase on } \\
\text { ambient } \mathrm{CO}_{2}\end{array}$ & $-1 \%$ in $\mathrm{CH}_{4}$ consumption*** & $\begin{array}{l}\text { Negative yet not significant } \\
\text { in } \mathrm{CH}_{4} \text { consumption }\end{array}$ & Kanerva et al. (2007) \\
\hline \multirow{6}{*}{$\mathrm{N}$ input } & \multirow[b]{2}{*}{ Forest } & Meta-analysis & \multirow{2}{*}{$\begin{array}{l}-0.32 \pm 0.02\left(\mathrm{mg} \mathrm{C} \mathrm{m}^{-2} \mathrm{a}^{-1} \text { per g }\right. \\
\left.\mathrm{N}^{-1} \mathrm{~m}^{-2} \mathrm{a}^{-1}\right) \text { in } \mathrm{CH}_{4} \text { uptake }\end{array}$} & $\begin{array}{l}17 \pm 5\left(\mathrm{mg} \mathrm{C} \mathrm{m}^{-2} \mathrm{a}^{-1}\right. \\
\left.\text { per g N } \mathrm{m}^{-2} \mathrm{a}^{-1}\right) \text { in } \mathrm{CH}_{4} \\
\text { uptake }\end{array}$ & Liu and Greaver (2009) \\
\hline & & $\begin{array}{l}\text { Field experiment with } \\
0,3.7 \text { and } \\
12 \mathrm{~g} \mathrm{~N} \mathrm{~m}^{-2} \mathrm{a}^{-1} \\
\text { application }\end{array}$ & & $\begin{array}{l}-10.75 \pm 3.98\left(\mathrm{mg} \mathrm{C} \mathrm{m}^{-2} \mathrm{a}^{-1}\right. \\
\left.\text { per g N } \mathrm{m}^{-1} \mathrm{a}^{-1}\right) \text { in } \mathrm{CH}_{4} \\
\text { uptake**** }\end{array}$ & Steudler et al. (1989) \\
\hline & \multirow[b]{2}{*}{ Wetland } & Meta-analysis & \multirow{2}{*}{$\begin{array}{l}272 \pm 15\left(\mathrm{mg} \mathrm{C} \mathrm{m} \mathrm{m}^{-2} \mathrm{a}^{-1}\right. \\
\left.\text { per g N} \mathrm{m}^{-2} \mathrm{a}^{-1}\right) \text { in } \mathrm{CH}_{4} \\
\text { emission }\end{array}$} & $\begin{array}{l}8 \pm 4\left(\mathrm{mg} \mathrm{C} \mathrm{g} \mathrm{N}^{-1} \mathrm{~m}^{-2}\right. \\
\left.\mathrm{a}^{-1}\right) \text { in } \mathrm{CH}_{4} \text { emission }\end{array}$ & Liu and Greaver (2009) \\
\hline & & $\begin{array}{l}\text { Field experiment with } \\
0 \text { and } 24 \mathrm{~g} \mathrm{~N} \mathrm{~m}^{-2} \mathrm{a}^{-1} \\
\text { application }\end{array}$ & & $\begin{array}{l}676\left(\mathrm{mg} \mathrm{C} \mathrm{g} \mathrm{N}^{-1} \mathrm{~m}^{-2} \mathrm{a}^{-1}\right) \text { in } \\
\mathrm{CH}_{4} \text { emission } * * * *\end{array}$ & Zhang et al. (2007c) \\
\hline & Grassland & Meta-analysis & $\begin{array}{l}-0.21 \pm 0.02\left(\mathrm{mg} \mathrm{C} \mathrm{m}^{-2} \mathrm{a}^{-1} \text { per } \mathrm{g}\right. \\
\left.\mathrm{N}^{-1} \mathrm{~m}^{-2} \mathrm{a}^{-1}\right) \text { in } \mathrm{CH}_{4} \text { uptake }\end{array}$ & $\begin{array}{l}0\left(\mathrm{mg} \mathrm{C} \mathrm{g} \mathrm{N} \mathrm{N}^{-1} \mathrm{~m}^{-2} \mathrm{a}^{-1}\right) \text { in } \mathrm{CH}_{4} \\
\text { uptake }\end{array}$ & Liu and Greaver (2009) \\
\hline & $\begin{array}{l}\text { Dry } \\
\text { cropland }\end{array}$ & Meta-analysis & $\begin{array}{l}7.43 \pm 1.09\left(\mathrm{mg} \mathrm{C} \mathrm{m}^{-2} \mathrm{a}^{-1} \text { per } \mathrm{g}\right. \\
\left.\mathrm{N}^{-1} \mathrm{~m}^{-2} \mathrm{a}^{-1}\right) \text { in } \mathrm{CH}_{4} \text { uptake }\end{array}$ & $\begin{array}{l}12 \pm 6\left(\mathrm{mg} \mathrm{C} \mathrm{g} \mathrm{N}^{-1} \mathrm{~m}^{-2} \mathrm{a}^{-1}\right) \text { in } \\
\mathrm{CH}_{4} \text { uptake }\end{array}$ & Liu and Greaver (2009) \\
\hline \multirow{2}{*}{$\mathrm{O}_{3}$ pollution } & Peat land & Double ambient $\mathrm{O}_{3}$ & $\begin{array}{l}\text { Negative yet not significant in } \\
\mathrm{CH}_{4} \text { emission }\end{array}$ & $\begin{array}{l}\text { Negative yet not significant } \\
\text { in } \mathrm{CH}_{4} \text { emission }\end{array}$ & Morsky et al. (2008) \\
\hline & meadow & $\begin{array}{l}\text { 10-20 ppb higher than } \\
\text { ambient }\end{array}$ & $\begin{array}{l}\text { Negative yet not significant in } \\
\mathrm{CH}_{4} \text { uptake }\end{array}$ & $\begin{array}{l}\text { Negative yet not significant } \\
\text { in } \mathrm{CH}_{4} \text { uptake }\end{array}$ & Kanerva et al. (2007) \\
\hline
\end{tabular}

* The value is estimated by the linear calculation based on regressed equation between atmospheric $\mathrm{CO}_{2}$ concentration (ppm) and annual $\mathrm{CH}_{4}$ emission from herbaceous wetland over North America $\left(Y=6.82 * X+4754.6, R^{2}=0.996, N=30\right)$.

** The value is estimated by the linearly calculation based on regressed equation between atmospheric $\mathrm{CO}_{2}$ concentration (ppm) and annual $\mathrm{CH}_{4}$ emission from forests over North America $\left(Y=0.01 * X-158.92, R^{2}=0.99, N=30\right)$.

*** The value is estimated by the linearly calculation based on regressed equation between atmospheric $\mathrm{CO}_{2}$ concentration (ppm) and annual $\mathrm{CH}_{4}$ emission from grassland over North America $\left(Y=0.05 * X-568.82, R^{2}=0.96, N=30\right)$.

**** Averaged for hardwood and pine temperate forest from the field experimental results with 200 days of frost-free days.

***** Calculated from the field experimental results in May, June, July, August the growing season of wetland vegetation.

The effects of $\mathrm{N}$ input were summarized based on meta-analysis in Liu and Greaver's study (2009); the effects in this study were calculated based on N deposition-induced changes in $\mathrm{CH}_{4}$ flux for forest, grassland, and wetland, and $\mathrm{N}$ fertilizer-induced changes in $\mathrm{CH}_{4}$ flux for dry cropland.

higher in high-latitudinal Canada than those in mid and low latitudinal US and Mexico (Davidson and Janssens, 2006), the increased temperature possibly leads to more DOC in Canada which is the substrate of $\mathrm{CH}_{4}$ production and finally leads to higher $\mathrm{CH}_{4}$ emission. This is consistent with previous studies (Zhuang et al., 2004, 2006). The increase in terrestrial $\mathrm{CH}_{4}$ flux over North America during 2005-2007 is primarily attributable to climate variability (Fig. 8); the increases in $\mathrm{CH}_{4}$ emission is consistent with the increase in atmospheric $\mathrm{CH}_{4}$ concentration in 2007 (Rigby et al., 2008; Dlugokencky et al., 2009), suggesting that the newly-found increase in atmospheric $\mathrm{CH}_{4}$ concentration in 2007 might be caused by global environment change, especially climate variability.

The contrasting effects of climate variability from 1979 to 2008 on the $\mathrm{CH}_{4}$ emissions from USA and Canada may be due to the different ecosystem responses to interactions among climate variables (Table 5). As reported that higher increases in air temperature and precipitation occur in
Canada than in USA (Groisman and Easterling, 1994; Christensen et al., 2007), which may lead to more substrate and more $\mathrm{CH}_{4}$ production and higher $\mathrm{CH}_{4}$ emission; this is consistent with a number of field observations (Schrope et al., 1999; Song et al., 2009). However, it should be noted that the single climate variables might played contrasting role in affecting terrestrial $\mathrm{CH}_{4}$ flux. For example, the temperature effect on $\mathrm{CH}_{4}$ emission is positive in the USA, yet negative in the Canada; while the effect of multiple factors interaction is positive in Canada, yet negative in the USA (Table 5).

\subsection{Interactions among multiple factors}

Through this study, we also found that the interactive effects among global change factors played an important role in contributing to terrestrial $\mathrm{CH}_{4}$ flux. The interaction among global change factors has been recognized long before (Dermody, 2006); most of the field experiment still treat it as negligible, although few experiments have introduced this in 
their experiment design (Xia et al., 2009; Reich et al., 2006). The interactive effects among more than three factors are still short of investigation (Heimann and Reichstein, 2008). This study shows that the modeling approach may serve as one complementary tool for the field experiments in addressing interactive effect among multiple factors.

\subsection{Uncertainties}

This study examined the factorial contributions to temporal and spatial variations in $\mathrm{CH}_{4}$ flux over North American terrestrial ecosystems during 1979-2008. There are several uncertainties which need to be eliminated in our future work. First, the climate data used in this study only cover the time period of 1979-2008; the legacy effects of the pre-1979 global change factors could not be included in this study; this might overestimate or underestimate the long-term accumulated $\mathrm{CH}_{4}$ flux. Second, most of the single factor effects on $\mathrm{CH}_{4}$ flux have not been fully validated because of the scarcity of the field experiments (Heimann and Reichstein, 2008). Third, some possible disturbances or environmental factors probably influencing $\mathrm{CH}_{4}$ flux were not included in this study; for example, the fire (Burke et al., 1997), thawfreezing cycle in high-latitudinal ecosystems (Turetsky and Louis, 2006; Mastepanov et al., 2008), and insect outbreak (Turetsky and Louis, 2006); all these factors will be important but challenging to be included in the process-based modeling approach. Fourth, the open water emission of $\mathrm{CH}_{4}$ is a globally significant $\mathrm{CH}_{4}$ source (Bastviken et al., 2004; Walter et al., 2006, 2007), which may contribute to the terrestrial $\mathrm{CH}_{4}$ budget, especially from inland small lakes or river (Walter et al., 2006, 2007). Fifth, the uncertainties caused by model structure, parameters, and input data might need to be evaluated for accurately quantifying the relative contribution of each factor to the regional $\mathrm{CH}_{4}$ flux. Last but not least, the mechanisms for $\mathrm{CH}_{4}$ flux in response to global change factors need to be improved in future studies, as the global change factors may yield different impacts on production and consumption of atmospheric $\mathrm{CH}_{4}$. Partitioning the effects of global change factors on $\mathrm{CH}_{4}$ production and consumption may be one of the major efforts improving our estimation of regional $\mathrm{CH}_{4}$ flux in the context of changing environment.

\section{Conclusions}

Factorial contributions to the spatial and temporal variations in $\mathrm{CH}_{4}$ flux over North America were examined at both continental and country levels by using a highly integrated process-based model driven by multiple global change factors including changing climate, $\mathrm{N}$ deposition, rising atmospheric $\mathrm{CO}_{2}, \mathrm{O}_{3}$ pollution, $\mathrm{N}$ fertilizer application, and land conversion. Although some uncertainties, the attribution of spatial and temporal variations in $\mathrm{CH}_{4}$ flux over North America to six factors and their interaction is helpful in advancing our understanding of the dynamics of atmospheric $\mathrm{CH}_{4}$ concentration; it might also benefit the policy-making for curbing the increase in atmospheric $\mathrm{CH}_{4}$ concentration. This study found the contrasting climatic effects on $\mathrm{CH}_{4}$ emissions from the USA and Canada. The complicated effects of multiple-factor interaction on $\mathrm{CH}_{4}$ flux suggest that the current experiments which usually ignore the interactive effects from multiple-factor may lead to biases in the estimation of $\mathrm{CH}_{4}$ flux. This study also pointed out that the models driven by few global change factors may bring bias in estimating $\mathrm{CH}_{4}$ flux. The climate-dominated inter-annual variations in $\mathrm{CH}_{4}$ flux pretends a changed regime of $\mathrm{CH}_{4}$ exchange between terrestrial ecosystems and the atmosphere in the response to projected climate change (Forster et al., 2007).

This study also provides insights for the examination of multiple-factor interactive effects on terrestrial $\mathrm{CH}_{4}$ flux. Given the advantages of modeling approach in quantifying regional $\mathrm{CH}_{4}$ flux and the importance of field experiments in model improvement and flux estimation, clearly, a collaborative effort between field ecologists and modelers is necessary for further investigation of the underlying mechanisms for spatial and temporal variations in $\mathrm{CH}_{4}$ exchange between terrestrial ecosystems and the atmosphere.

Acknowledgements. This study has been supported by NASA Atmospheric Chemistry Modeling and Analysis Program, DOE NICCR, NASA Terrestrial Ecology Program, USDA CSREES Projects. This study contributes to the NACP Non- $\mathrm{CO}_{2}$ Greenhouse Gases Synthesis led by Steven Wofsy at Harvard University. We thank Dafeng Hui from the Tennessee State University, Yao Huang from the Institute of Atmospheric Physics, and Janusz Eluszkiewicz and Vivenne Payne from the Atmospheric and Environmental Research Incorporation for critical comments which greatly improved this manuscript.

Edited by: E. Falge

\section{References}

Amaral, J. A., Ren, T., and Knowles, R.: Atmospheric methane consumption by forest soils and extracted bacteria at different pH values, Appl. Environ. Microb., 64, 2397-2402, 1998.

Ambus, P. and Robertson, G. P.: Fluxes of $\mathrm{CH}_{4}$ and $\mathrm{N}_{2} \mathrm{O}$ in aspen stands grown under ambient and twice-ambient $\mathrm{CO}_{2}$, Plant Soil, 209, 1-8, 1999.

Bastviken, D., Cole, J., Pace, M., and Tranvik, L.: Methane emissions from lakes: Dependence of lake characteristics, two regional assessments, and a global estimate, Global Biogeochem. Cy., 18, GB4009, doi:10.1029/2004GB002238, 2004.

Bodelier, P. L. E., Roslev, P., Henckel, T., and Frenzel, P.: Stimulation by ammonium-based fertilizers of methane oxidation in soil around rice roots, Nature, 403, 421-424, 2000.

Börjesson, G. and Nohrstedt, H.: Short-and long-term effects of nitrogen fertilization on methane oxidation in three Swedish forest soils, Biol. Fert. Soils, 27, 113-118, 1998. 
Bosse, U., Frenzel, P., and Conrad, R.: Inhibition of methane oxidation by ammonium in the surface layer of a littoral sediment, FEMS Microbiol. Ecol., 13, 123-134, 1993.

Bousquet, P., Ciais, P., Miller, J., Dlugokencky, E., Hauglustaine, D., Prigent, C., Van der Werf, G., Peylin, P., Brunke, E., and Carouge, C.: Contribution of anthropogenic and natural sources to atmospheric methane variability, Nature, 443, 439-443, 2006.

Bridgham, S. D., Megonigal, J. P., Keller, J. K., Bliss, N. B., and Trettin, C.: The carbon balance of North American Wetlands, Wetlands, 26, 889-916, 2006.

Burke, R., Zepp, R., Tarr, M., Miller, W., and Stocks, B.: Effect of fire on soil-atmosphere exchange of methane and carbon dioxide in Canadian boreal forest sites, J. Geophys. Res.-Atmos., 102(D24), 29289-29300, doi:10.1029/97JD01331, 1997.

Cao, M. K., Gregson, K., and Marshall, S.: Global methane emission from wetlands and its sensitivity to climate change, Atmos. Environ., 32, 3293-3299, 1998.

Chen, G., Tian, H., Liu, M., Ren, W., Zhang, C., and Pan, S.: Climate impacts on China's terrestrial carbon cycle: an assessment with the dynamic land ecosystem model, in: Environmental Modelling and Simulation, edited by: Tian, H. Q., ACTA Press, Anahiem/Calgary/Zurich, 56-70, 2006.

Chen, Y. H. and Prinn, R. G.: Estimation of atmospheric methane emissions between 1996 and 2001 using a three-dimensional global chemical transport model, J. Geophys. Res.-Atmos., 111, D10307, doi:10.1029/2005JD006058, 2006.

Cheng, W., Yagi, K., Sakai, H., and Kobayasi, K.: Effects of elevated atmospheric $\mathrm{CO}_{2}$ concentrations on $\mathrm{CH}_{4}$ and $\mathrm{N}_{2} \mathrm{O}$ emission from rice soil: an experiment in controlled-environment chambers, Biogeochemistry, 77, 351-373, 2006.

Conrad, R.: Soil microorganisms as controllers of atmospheric trace gases $\left(\mathrm{H}_{2}, \mathrm{CO}, \mathrm{CH}_{4}, \mathrm{OCS}, \mathrm{N}_{2} \mathrm{O}\right.$, and $\left.\mathrm{NO}\right)$, Microbiol. Rev., 60, 609-640, 1996.

Curry, C. L.: The consumption of atmospheric methane by soil in a simulated future climate, Biogeosciences, 6, 2355-2367, doi:10.5194/bg-6-2355-2009, 2009.

Dacey, J., Drake, B., and Klug, M.: Stimulation of methane emission by carbon dioxide enrichment of marsh vegetation, Nature, 370, 47-49, doi:10.1038/370047a0, 1994.

Davidson, E. A. and Janssens, I. A.: Temperature sensitivity of soil carbon decomposition and feedbacks to climate change, Nature, 440, 165-173, doi:10.1038/nature04514, 2006.

De Fries, R., Hansen, M., Townshend, J., and Sohlberg, R.: Global land cover classifications at $8 \mathrm{~km}$ spatial resolution: the use of training data derived from Landsat imagery in decision tree classifiers, Int. J. Remote Sens., 19, 3141-3168, 1998.

Denman, K. L., Brasseur, G., Chidthaisong, A., Ciais, P., Cox, P. M., Dickinson, R. E., Hauglustaine, D., Heinze, C., Holland, E., Jacob, D., Lohmann, U., Ramachandran, S., da Silva Dias, P. L., Wofsy, S. C., and Zhang, X.: Couplings between changes in the climate system and biogeochemistry, in: Climate change 2007: The physical science basis, Contribution of working group I to the fouth assessment report of the intergovernmanetal panel on climate change, edited by: Solomon, S., Qin, D., Manning, M., and Chen, Z., Cambridge Univeristy Press, Cambridge, United Kingdom and New York, USA, 2007.

Dentener, F., Drevet, J., Lamarque, J., Bey, I., Eickhout, B., Fiore, A., Hauglustaine, D., Horowitz, L., Krol, M., and Kulshrestha, U.: Nitrogen and sulfur deposition on regional and global scales:
A multimodel evaluation, Global Biogeochem. Cy., 20, GB4003, doi:10.1029/2005GB002672, 2006.

Dermody, O.: Mucking through multifactor experiments; design and analysis of multifactor studies in global change research, New Phytol., 172, 598-600, 2006.

Ding, W., Cai, Z., and Wang, D.: Preliminary budget of methane emissions from natural wetlands in China, Atmos. Environ., 38, 751-759, 2004a.

Ding, W. X., Cai, Z. C., and Tsuruta, H.: Cultivation, nitrogen fertilization, and set-aside effects on methane uptake in a drained marsh soil in Northeast China, Glob. Change Biol., 10, 18011809, 2004b.

Dlugokencky, E. J., Bruhwiler, L., White, J. W. C., Emmons, L. K., Novelli, P. C., Montzka, S. A., Masarie, K. A., Crotwell, A. M., Miller, J. B., and Gatti, L. V.: Observational constraints on recent increases in the atmospheric $\mathrm{CH}_{4}$ burden, Geophys. Res. Lett., 36, L18803, doi:10.1029/2009GL039780, 2009.

Dunfield, P. and Knowles, R.: Kinetics of inhibition of methane oxidation by nitrate, nitrite, and amonium in a humisol, Appl. Environ. Microb., 61, 3129-3135, 1995.

Felzer, B., Reilly, J., Melillo, J., Kicklighter, D., Sarofim, M., Wang, C., Prinn, R., and Zhuang, Q.: Future effects of ozone on carbon sequestration and climate change policy using a global biogeochemical model, Climatic Change, 73, 345-373, doi:10.1007/s10584-005-6776-4, 2005.

Forster, P., Ramaswamy, V., Artaxo, P., Berntsen, T., Betts, R., Fahey, D. W., Haywood, J., Lean, J., Lowe, D. C., Myhre, G., Nganga, J., Prinn, N. R., Raga, G., Schulz, M., and Dorland, R. V.: Changes in atmospheric constituents and in radiative forcing, in: Climate change 2007: The physical science basis, Contribution of working group I to the fouth assessment report of the intergovernmanetal panel on climate change, edited by: Solomon, S., Qin, D., Manning, M., and Chen, Z., Cambridge Univeristy Press, Cambridge, United Kingdom and New York, USA, 2007.

Frolking, S. and Crill, P.: Climate controls on temporal variability of methane flux from a poor fen in southeastern New Hampshire: Measurement and modeling, Global Biogeochem. Cy., 8, 385397, 1994.

Groisman, P. and Easterling, D.: Variability and trends of total precipitation and snowfall over the United States and Canada, J. Climate, 7, 184-205, 1994.

Heimann, M. and Reichstein, M.: Terrestrial ecosystem carbon dynamics and climate feedbacks, Nature, 451, 289-292, doi:10.1038/nature06591, 2008.

Huang, Y., Sun, W., Zhang, W., Yu, Y., Su, Y., and Song, C.: Marshland conversion to cropland in northeast China from 1950 to 2000 reduced the greenhouse effect, Glob. Change Biol., 16, 680-695, doi:10.1111/j.1365-2486.2009.01976.x, 2010.

Hutchin, P. R., Press, M. C., Lee, J. A., and Ashenden, T. W.: Elevated concentrations of $\mathrm{CO}_{2}$ may double methane emissions from mires, Glob. Change Biol., 1, 125-128, 1995.

Inubushi, K., Furukawa, Y., Hadi, A., Purnomo, E., and Tsuruta, H.: Seasonal changes of $\mathrm{CO}_{2}, \mathrm{CH}_{4}$ and $\mathrm{N}_{2} \mathrm{O}$ fluxes in relation to land-use change in tropical peatlands located in coastal area of South Kalimantan, Chemosphere, 52, 603-608, 2003.

Jiang, C., Wang, Y., Hao, Q., and Song, C.: Effect of land-use change on $\mathrm{CH}_{4}$ and $\mathrm{N}_{2} \mathrm{O}$ emissions from freshwater marsh in Northeast China, Atmos. Environ., 43, 3305-3309, 2009.

Kanerva, T., Regina, K., Rämö, K., Ojanperä, K., and Manninen, S.: 
Fluxes of $\mathrm{N}_{2} \mathrm{O}, \mathrm{CH}_{4}$ and $\mathrm{CO}_{2}$ in a meadow ecosystem exposed to elevated ozone and carbon dioxide for three years, Environ. Pollut., 145, 818-828, 2007.

Klein, G. K. and van Drecht, G.: HYDE 3: Current and historical population and land cover, in: Integrated modelling of global environmental change. An overview of IMAGE 2.4., edited by: Bouwman, A. F., Kram, T., and Klein G. K., Netherlands Environmental Assessment Agency (MNP), Bilthoven, The Netherlands, 2006.

LeBauer, D. S. and Treseder, K. K.: Nitrogen limitation of net primary productivity in terrestrial ecosystems is globally distributed, Ecology, 89, 371-379, 2008.

Lehner, B. and Döll, P.: Development and validation of a global database of lakes, reservoirs and wetlands, J. Hydrol., 296, 1-22, 2004.

Lelieveld, J. and Crutzen, P. J.: Indirect chemical effects of methane on climate warming, Nature, 355, 399-402, 1992.

Liu, L. and Greaver, T.: A review of nitrogen enrichment effects on three biogenic GHGs: the $\mathrm{CO}_{2}$ sink may be largely offset by stimulated $\mathrm{N}_{2} \mathrm{O}$ and $\mathrm{CH}_{4}$ emission, Ecol. Lett., 12, 1103-1117, 2009.

Liu, M., Tian, H., Chen, G., Ren, W., Zhang, C., and Liu, J.: Effects of land-use and land-cover change on evapotranspiration and water yield in China during 1900-2000, J. Am. Water Resour. As., 44, 1193-1207, 2008.

Liu, Y.: Modeling the emissions of nitrous oxide $\left(\mathrm{N}_{2} \mathrm{O}\right)$ and methane $\left(\mathrm{CH}_{4}\right)$ from the terrestrial biosphere to the atmosphere, Doctor of Philisophy in Global Change Science, Department of Earth, Atmospheric and Planetary Sciences, Massachusetts Institute of Technology, Boston, 1996.

Lu, C.: Atmospheric nitrogen deposition and terrestrial ecosystem carbon cycle in China, Dissertation, Chinese Academy of Sciences, Beijing, 2009.

Magnani, F., Mencuccini, M., Borghetti, M., Berbigier, P., Berninger, F., Delzon, S., Grelle, A., Hari, P., Jarvis, P. G., Kolari, P., Kowalski, A. S., Lankreijer, H., Law, B. E., Lindroth, A., Loustau, D., Manca, G., Moncrieff, J. B., Rayment, M., Tedeschi, V., Valentini, R., and Grace, J.: The human footprint in the carbon cycle of temperate and boreal forests, Nature, 447, 848-850, doi:10.1038/nature05847, 2007.

Martikainen, P. J., Nykänen, H., Crill, P., and Silvola, J.: Effect of a lowered water table on nitrous oxide fluxes from northern peatlands, Nature, 366, 51-53, 1993.

Mastepanov, M., Sigsgaard, C., Dlugokencky, E. J., Houweling, S., Strom, L., Tamstorf, M. P., and Christensen, T. R.: Large tundra methane burst during onset of freezing, Nature, 456, 628-630, 07464, doi:10.1038/nature07464, 2008.

McGuire, A., Sitch, S., Clein, J., Dargaville, R., Esser, G., Foley, J., Heimann, M., Joos, F., Kaplan, J., Kicklighter, D., Meler, R. A., Melillo, J. M., Moore III, B., Prentice, I. C., Ramankutty, N., Reichenau, T., Schloss, A., Tian, H. Q., Willams, L. J., and Wittenberg, U.: Carbon balance of the terrestrial biosphere in the twentieth century: Analyses of $\mathrm{CO}_{2}$, climate and land use effects with four process-based ecosystem models, Global Biogeochem. Cy., 15, 183-206, 2001.

Megonigal, J. and Schlesinger, W.: Enhanced $\mathrm{CH}_{4}$ emission from a wetland soil exposed to elevated $\mathrm{CO}_{2}$, Biogeochemistry, 37, 77-88, 1997.

Mer, J. L. and Roger, P.: Production, oxidation, emission and con- sumption of methane by soils: a review, Eur. J. Soil Biol., 37, 25-50, 2001.

Mesinger, F., DiMego, G., Kalnay, E., Mitchell, K., Shafran, P. C., Ebisuzaki, W., Jovic, D., Woollen, J., Rogers, E., Berbery, E. H., Ek, M. B., Fan, Y., Grumbine, R., Higgins, W., Li, H., Lin, Y., Manikin, G., Parrish, D., and Shi, W.: North American regional reanalysis, B. Am. Meteorol. Soc., 87, 343-360, 2006.

Moosavi, S. C., Crill, P. M., Pullman, E. R., Funk, D. W., and Peterson, K. M.: Controls on $\mathrm{CH}_{4}$ flux from an Alaskan boreal wetland, Global Biogeochem. Cy., 10, 287-296, 1996.

Morris, J. T.: Effects of nitrogen loading on wetland ecosystems with particular reference to atmospheric deposition, Annu. Rev. Ecol. Syst., 22, 257-279, 1991.

Morsky, S., Haapala, J. K., Rinnan, R. A., Tiiva, P., Saarnio, S., Silvola, J., Holopalinen, T., and Martikainen, P. J..: Long-term ozone effects on vegetation, microbial community and methane dyanmics of boreal peatland microcosms in open-field conditions, Glob. Change Biol., 14, 1891-1903, doi:10.1111/j.13652486,2008.01615.x, 2008.

Nold, S. C., Boschker, H. T. S., Pel, R., and Laanbroek, H. J.: Ammonium addition inhibits ${ }^{13} \mathrm{C}$-methane incorporation into methanotroph membrane lipids in a freshwater sediment, FEMS Microbiol. Ecol., 29, 81-89, 1999.

Phillips, R. L., Whalen, S. C., and Schlesinger, W. H.: Influence of atmospheric $\mathrm{CO}_{2}$ enrichment on methane consumption in a temperate forest soil, Glob. Change Biol., 7, 557-563, 2001.

Potter, C., Klooster, S., Hiatt, S., Fladeland, M., Genovese, V., and Gross, P.: Methane emissions from natural wetlands in the United States: satellite-derived estimation based on ecosystem carbon cycling, Earth Interact., 10, 1-12, 2006.

Potter, C. S.: An ecosystem simulation model for methane production and emission from wetlands, Global Biogeochem. Cy., 11 495-506, 1997.

Reich, P. B., Knops, J., Tilman, D., Craine, J., Ellsworth, D., Tjoelker, M., Lee, T., Wedin, D., Naeem, S., Bahauddin, D., Hendrey, G., Jose, S., Wrage, K., Goth, J., and Bengston, W.: Plant diversity enhances ecosystem responses to elevated $\mathrm{CO}_{2}$ and nitrogen deposition, Nature, 410, 809-812, 2001.

Reich, P. B., Hobbie, S. E., Lee, T., Ellsworth, D. S., West, J. B., Tilman, D., Knops, J. M. H., Naeem, S., and Trost, J.: Nitrogen limitation constrains sustainability of ecosystem response to $\mathrm{CO}_{2}$, Nature, 440, 922-925, doi:10.1038/nature04486, 2006.

Ren, W., Tian, H., Liu, M., Zhang, C., Chen, G., Pan, S., Felzer, B., and Xu, X.: Effects of tropospheric ozone pollution on net primary productivity and carbon storage in terrestrial ecosystems of China, J. Geophys. Res.-Atmos., 112, D22S09, doi:10.1029/2007jd008521, 2007.

Ren, W.: Effects of Ozone Pollution and Climate Variability/Change on Spatial and Temporal Patterns of Terrestrial Primary Productivity and Carbon Storage in China, Dissertation, School of Forestry and Wildlife Science, Auburn University, Auburn, 202 pp., 2009.

Ridgwell, A. J., Marshall, S. J., and Gregson, K.: Consumption of atmospheric methane by soils: a process-based model, Global Biogeochem. Cy., 13, 59-70, 1999.

Rigby, M., Prinn, R. G., Fraser, P. J., Simmonds, P. G., Langenfelds, R. L., Huang, J., Cunnold, D. M., Steele, L. P., Krummel, P. B., Weiss, R. F., O’Doherty, S., Salameh, P. K., Wang, H. J., Harth, C. M., Muhle, J., and Porter, L. W.: Re- 
newed growth of atmospheric methane, Geophys. Res. Lett., 35, L22805, doi:10.1029/2008GL036037, 2008.

Rodhe, H.: A comparison of the contribution of various gases to the greenhouse effect, Science, 248, 1217-1219, 1990.

Saarnio, S., Alm, J., Martikainen, P. J., and Silvola, J.: Effects of raised $\mathrm{CO}_{2}$ on potential $\mathrm{CH}_{4}$ production and oxidation in, and $\mathrm{CH}_{4}$ emission from, a boreal mire, J. Ecol., 86, 261-268, 1998.

Saarnio, S. and Silvola, J.: Effects of increased $\mathrm{CO}_{2}$ and $\mathrm{N}$ on $\mathrm{CH}_{4}$ efflux from a boreal mire: a growth chamber experiment, Oecologia, 119, 349-356, 1999.

Schimel, D., Melillo, J. M., Tian, H., McGuire, A. D., Kicklighter, D. W., Kittel, T., Rosenbloom, N., Running, S., Thornton, P., and Ojima, D.: Contribution of increasing $\mathrm{CO}_{2}$ and climate to carbon storage by ecosystems in the United States, Science, 287, 2004-2006, 2000.

Schimel, J.: Biogeochemical models: implicit vs. explicit microbiology, in: Global Biogeochemical Cycles in the Climate Systems, Academic Press, New York, 177-183, 2001.

Schnell, S. and King, G. M.: Mechanistic analysis of ammonium inhibition of atmospheric methane consumption in forest soils, Appl. Environ. Microb., 60, 3514-3521, 1994.

Schrope, M. K., Chanton, J. P., Allen, L. H., and Baker, T. J.: Effect of $\mathrm{CO}_{2}$ enrichment and elevated temperature on methane emissions from rice, Oryza sativa, Glob. Change Biol., 5, 587-599, 1999.

Sellers, P. J., Hall, F. G., Kelly, R. D., Black, A., Baldocchi, D., Berry, J., Ryan, M., Ranson, K. J., Crill, P. M., Lettenmaier, D. P., Margolis, H., Cihlar, J., Newcomer, J., Fitzjarrald, D., Jarvis, P. G., Gower, S. T., Halliwell, D., Williams, D., Goodison, B., Wickland, D. E., and Guertin, F. E.: BOREAS in 1997: Experiment overview, scientific results, and future directions, J. Geophys. Res.-Atmos., 102, 28731-28769, 1997.

Shindell, D. T., Faluvegi, G., Bell, N., and Schmidt, G. A.: An emissions-based view of climate forcing by methane and tropospheric ozone, Geophys. Res. Lett., 32, L04803, doi:10.1029/2004GL021900, 2005.

Silvola, J., Saarnio, S., Foot, J., Sundh, I., Greenup, A., Heijmans, M., Ekberg, A., Mitchell, E., and van Breemen, N.: Effects of elevated $\mathrm{CO}_{2}$ and $\mathrm{N}$ deposition on $\mathrm{CH}_{4}$ emissions from european mires, Global Biogeochem. Cy., 17(2), 1068, doi:10.1019/2002GB001886, 2003.

Song, C., Xu, X., Tian, H., and Wang, Y.: Ecosystem-atmosphere exchange of $\mathrm{CH}_{4}$ and $\mathrm{N}_{2} \mathrm{O}$ and ecosystem respiration in wetlands in the Sanjiang Plain, Northeastern China, Glob. Change Biol., 15, 692-705, 2009.

Steudler, P. A., Bowden, R. D., Melillo, J. M., and Aber, J. D.: Influence of nitrogen fertilization on methane uptake in temperate forest soils, Nature, 341, 314-316, 1989.

Tian, H., Hall, C., and Qi, Y.: Modeling primary productivity of the terrestrial biosphere in changing environments: toward a dynamic biosphere model, Crit. Rev. Plant Sci., 17, 541-557, 1998.

Tian, H., Xu, X., Zhang, C., Ren, W., Chen, G., Liu, M., Lu, D., and Pan, S.: Forecasting and assessing the large-scale and long-term impacts of global environmental change on terrestrial ecosystems in the United States and China, in: Real world ecology: largescale and long-term case studies and methods, edited by: Miao, S., Carstenn, S., and Nungesser, M., Springer, New York, 2008.

Tian, H., Xu, X., Liu, M., Ren, W., Zhang, C., Chen, G., and Lu, C.: Spatial and temporal patterns of $\mathrm{CH}_{4}$ and $\mathrm{N}_{2} \mathrm{O}$ fluxes in terrestrial ecosystems of North America during 1979-2008: application of a global biogeochemistry model, Biogeosciences, 7, 2673-2694, doi:10.5194/bg-7-2673-2010, 2010a.

Tian, H., Chen, G., Liu, M., Zhang, C., Sun, G., Lu, C., Xu, X., Ren, W., Pan, S., and Chappelka, A.: Model estimates of net primary productivity, evapotranspiration, and water use efficiency in the terrestrial ecosystems of the southern United States during 1895 2007, Forest Ecol. Manag., 259, 1311-1327, 2010 b.

Turetsky, M. and Louis, V.: 16 Disturbance in Boreal Peatlands, Boreal Peatland Ecosystems, 359-379, (With 22 Tables), 2006.

Vann, C. D. and Megonigal, J. P.: Elevated $\mathrm{CO}_{2}$ and water depth regulation of methnae emissions: comparison of woody and nonwoody wetland plant species, Biogeochemistry, 63, 117-134, 2003.

Walter, B. P., Heimann, M., and Matthews, E.: Modeling modern methane emissions from natural wetlands, 1 . model description and results, J. Geophys. Res., 106, 34189-34206, 2001.

Walter, K. M., Zimov, S. A., Chanton, J. P., Verbyla, D., and Chapin, F. S.: Methane bubbling from Siberian thaw lakes as a positive feedback to climate warming, Nature, 443, 71-75, 2006.

Walter, K. M., Smith, L. C., and Chapin, F. S.: Methane bubbling from northern lakes: present and future contributions to the global methane budget, Philos. T. R. Soc. A, 365, 1657, doi:10.1098/rsta.2007.2036, 2007.

Willison, T. W., Coulding, K. W. T., and Powlson, D. S.: Effect of land-use change and methane mixing ratio on methane uptake from United Kingdom soil, Glob. Change Biol. 1, 209-212, 1995.

Wofsy, S. C. and Harriss, R. C.: The North American Carbon Program (NACP), Report of the NACP Committee of the US Interagency Carbon Cycle Science Program, Washington, DC, US Global Change Research Program, 2002.

Xia, J., Han, Y., Zhang, Z., Zhang, Z., and Wan, S.: Effects of diurnal warming on soil respiration are not equal to the summed effects of day and night warming in a temperate steppe, Biogeosciences, 6, 1361-1370, doi:10.5194/bg-6-1361-2009, 2009.

$\mathrm{Xu}, \mathrm{X}$.: Modeling methane exchange between the atmosphere and marshland over China during 1949-2008: magnitude, spatiotemporal distribution and attribution, Dissertation, Institute of Geographical Science and Natural Resource Research, Chinese Academy of Sciences, Beijing, p. 144, 2010.

Zhang, C., Tian, H., Chappelka, A., Ren, W., Chen, H., Pan, S., Liu, M., Styers, D., Chen, G., and Wang, Y.: Impacts of climatic and atmospheric changes on carbon dynamics in the Great Smoky Mountains National Park, Environ. Pollut., 149, 336-347, 2007a.

Zhang, C.: Terrestrial carbon dynamics of southern United States in response to changes in climate, atmosphere, and land-use/land cover from 1895 to 2005, Dissertation, School of Forestry and Wildlife Scicnes, Auburn University, Auburn, 248 pp., 2008.

Zhang, L. H., Song, C. C., Wang, D. X., Wang, Y. Y., and $\mathrm{Xu}, \mathrm{X}$. F.: The variation of methane emission from freshwater marshes and response to the exogenous $\mathrm{N}$ in Sanjiang Plain Northeast China, Atmos. Environ., 41, 4063-4072, doi:10.1016/j.atmosenv.2007.01.013, 2007b.

Zhang, L. H., Song, C. C., Zheng, X. H., Wang, D. X., and Wang, Y. Y.: Effects of nitrogen on the ecosystem respiration, $\mathrm{CH}_{4}$ and $\mathrm{N}_{2} \mathrm{O}$ emissions to the atmosphere from the freshwater marshes in northeast China, Environ. Geol., 52, 529-539, doi:10.1007/s00254-006-0485-9, 2007c. 
Zhuang, Q., Melillo, J. M., Kicklighter, D. W., Prinn, R. G., McGuire, A. D., Steudler, P. A., Felzer, B. S., and Hu, S.: Methane fluxes between terrestrial ecosystems and the atmosphere at northern high latitudes during the past century: A retrospective analysis with a process-based biogeochemistry model, Global Biogeochem. Cy., 18, GB3010, doi:3010.1029/2004GB002239, 2004.

Zhuang, Q., Melillo, J. M., Sarofim, M. C., Kicklighter, D. W., McGuire, A. D., Felzer, B. S., Sokolov, A., Prinn, R. G., Steudler, P. A., and $\mathrm{Hu}, \mathrm{S}$.: $\mathrm{CO}_{2}$ and $\mathrm{CH}_{4}$ exchanges between land ecosystems and the atmosphere in northern high latitudes over the 21st century, Geophys. Res. Lett., 33, L17403, doi:10.1029/2006GL026972, 2006.
Zhuang, Q., Melillo, J. M., McGuire, A. D., Kicklighter, D. W., Prinn, R. G., Steudler, P. A., Felzer, B. S., and Hu, S.: Net emissions of $\mathrm{CH}_{4}$ and $\mathrm{CO}_{2}$ in Alaska: Implications for the region's greenhouse gas budget, Ecol. Appl., 17, 203-212, 2007.

Zou, J., Huang, Y., Jiang, J., Zheng, X., and Sass, R.: A 3-year field measurement of methane and nitrous oxide emissions from rice paddies in China: Effects of water regime, crop residue, and fertilizer application, Global Biogeochem. Cy., 19, GB2021, doi:10.1029/2004GB002401, 2005. 